\title{
Sünnî Olmayan Mezheplerde Karşı Cinse Dokunmanın Abdeste Etkisi
}

\author{
Yakup Mahmutoğlu \\ Dr., Bayburt Üniversitesi, İlahiyat Fakültesi, İslam Hukuku Anabilim Dalı \\ Dr., Bayburt University, Divinity Faculty, Department of Islamic Law \\ Bayburt, Turkey \\ ymahmutoglu@gmail.com \\ orcid.org/0000-0002-0362-659X

\section{İdris Cebeci} \\ Doktora Öğrencisi, Bayburt Üniversitesi, Lisansüstü Eğitim Enstitüsü \\ Ph.D. Student, Bayburt University, Graduate Education Institute \\ Bayburt, Turkey \\ idriscebeci47@hotmail.com \\ orcid.org/0000-0003-2752-0906
}

\section{Effect of Touching the Opposite Sex on Ablution in Sects which are not Sunni}

\section{Abstract}

Islam placed great emphasis on an uninterrupted link between the servant and the creator. Undoubtedly, one of the most important elements that strengthen this link is the sincere worship of the servant to the God. Since prayer (salāt), on the other hand, is the most important of these worships, the ablution and dry ablution (tayammum), which are accepted as a preparation for prayer, were considered as important.

In the Qur'ān, ablution and dry ablution topics are dealt as detached in verse 6 of al-Māidah and verse 43 of al-Nisā. As a result of the efforts made by Islamic scholars towards understanding these two verses, many comments and Islamic judicial opinion emerged.

One of the most important disputes that arise in the context of these two verses is whether touching the opposite sex has spoil the ablution or dry ablution. There have been many disputes about what is meant in the aforementioned verses from the first period ('așr al-sa'adah) namely; the following statement mentioned as one of the situations in which ablution and dry ablution should be taken: “... أو لامستم النساء (aw lämastum al-nisäa/or when you touch women)..." some scholars said, the statement of ( aw lämastum al-nisä’a/or when you touch women )" means, touch; some said it means touch with lust, others said it was figuratively sexual intercourse (jimā). Based on these different meanings, some scholars have expressed an Islamic judicial opinion as "touching the opposite sex in absolute terms", some "touching only with lust" and others "sexual intercourse with women" spoils the ablution and dry ablution.

In the study, the opinions of the non-Sunnī Shiite-Jafarī, Shiite-Zaydīs and Khāriji--Ibāzīs sects on the subject of "lams/mulāmasa (touch, intercourse)" in the context of the relevant verses, reason ('aql) and revealed (naql) evidences based on their opinions, and their answers to scholars and sects in opposition to defend their views, were made by referring to basic resources as much as possible.

İntihal Taraması/Plagiarism Detection: Bu makale intihal taramasından geçirildi/This paper was checked for plagiarism Geliş/Received: 17 Aralik/December 2019|Kabul/Accepted:06 Mart/March 2020 |Yayın/Published: 20 Mart/March 2020 Atff/Cite as: Yakup Mahmutoğlu - İdris Cebeci, "Sünnî Olmayan Mezheplerde Karşı Cinse Dokunmanın Abdeste Etkisi = Effect of Touching the Opposite Sex on Ablution in Sects Which are not Sunni", Eskiyeni 40 (Mart/March 2020), 9-35. https://doi.org/10.37697/eskiyeni.660193

Copyright (c) Anadolu Illahiyat Akademisi/Anatolian Theological Academy, 06050, Ankara, Turkey |www.anilakademi.com CC BY-NC 4.0 | This paper is licensed under a Creative Commons Attribution-NonCommercial License 
When dealing with the subject, firstly, the meaning of the words "lamasa/lāmasa" in the mentioned verses is referred in some important classical dictionaries, in the meaning of the works such as Gharib al-Qur'ān and in tafsīr (Qur'ān interpretation) sources. The reading of the related verses, how these differences were evaluated by various Qur'ān recitations (qira'at) and Islamic jurists, and their effects on meaning were revealed. Afterwards, the verses (al-Māidah 5/6, al-Nisā 4/43) and hadīths were mentioned with their meanings and were briefly evaluated in order to provide a basis for the views of non-Sunnī sects. In this context, the approaches of Jafarī, whose understanding of hadith method is different from others, to the concept of hadith/narration, are briefly given.

After the foregoing explanations made above, the views and evidence of non-Sunni sects on lams/mulāmasa (touching) were revealed in detail and the following findings were reached: The Shiite-Jafarī tried to explain the issue of lams/mulāmasa only with the narrations coming from the imams of the People of the Household (ahl al-bayt) especially in the early periods due to their hadith understanding and some sectarian attitudes. Other did not include any narrations (transcripts) from many companions (șahabah) and tabi in (ones who saw șahabah). They also did not need to refer rational ('aqli) and dictionary-based evidence. In this respect, it is possible to say that they exhibit a very different and/or protective approach compared to other sects. However, it was observed that Jafaris displayed different methods within the sect while dealing with the subject of mulāmasa in the historical process. For example, the first scholars of the Shiite-Jafarīs belonging to the Ahbāri tradition understood this subject only in the light of the narrations from the imams. They strongly opposed to resort to any other evidence than these narrations. Whereas the Usūlis (and especially the 6th century scholar Tabarsii) that emerged in later periods, in addition to the narrations from the innocent imams, also took into account the companions of Prophet Mohammad (șahabah), ones who saw șahabah (tabiin) and the narratives from the Sunnī scholars, as well as the rational ('aqlī) and dictionary-based evidences. As a result, Jafarī accepted the view that the expression ".... أو لامستم النساء (ant (aw lämastum al-nisā'a ..." in the relevant verses is a metaphorical sexual intercourse in the light of the narrations coming from the imams. Therefore, they argued that regardless of whether they were mahram (within the relationships forbidden for marriage) or nāmahram (unrelated), opposite sex kissing or touching each other would in no way spoil the ablution. Regarding this view, it was also said that there was no conflict within the sect and even an alliance (ijmā).

While the Shiite-Zaydīs also included an inference on lams/mulāmasa, unlike the Jafaris, they included not only the narrations coming from imams of the People of the Household (ahl al-bayt) but also many hadiths and narrations in the sources regarded as valid by the sects outside the Shiites. Again, contrary to the Jafaris, they tried to support their views with rational and dictionary-based evidence. For this reason, it can be said that the Zaydîs behaved relatively more positively about the mulāmasa. Zaydīs stated that the purpose of the expression “.... أو لامستم النساء (aw lāmastum al-nisā’a ...” is a metaphorically sexual relationship according to the narrations that come through the companion of Prophet Mohammad, ones who saw șahabah and imams. In this respect, they adopted the view that men and women touching each other, regardless of whether they are mahram or nāmahram, will in no way spoil the ablution.

On the other hand, the Khārijī-lbāzīs focused more on stains (al-najasa) and sin when they were writing the ablution situations in their early works. For this reason, it was observed that touching the opposite sex did not specifically deal with ablution. Therefore, they did not pay much attention to the fact that the expression “.... أو لامستم النساء (aw lāmastum al-nisä’a ...” in the relevant verses is true or metaphorical. However, it has been observed that they have devoted quite a lot to the subject of mulāmasa in their recent works, especially Ma'arij al-A'mâl. Therefore, according to the Ibāzīs, since the words of lamasa/lämasa in the relevant verses are sexual intercourse in a figurative sense, the absolute touching the opposite sex does not spoil ablution. However, because they argue that any bad words and behaviors that are accepted as sin will spoil ablution, these people said that looking or 
touching the woman's body (the whole body except hand and face), which is forbidden to look at, will spoil ablution. And either they said that looking and touching with lust in places where it is not forbidden to look will destroy the ablution. In addition, it was observed that they used almost every hadith/narration that supports their views as evidence, regardless of whether they are authentic or not.

\section{Keywords}

Islamic Law, Jafarī, Zaydī, Ibāzī, Ablution, Touch

\section{Sünnî Olmayan Mezheplerde Karşı Cinse Dokunmanın Abdeste Etkisi}

\section{Öz}

İslâm dini, kul ile yaratıcısı arasında kesintisiz bir bağın bulunmasına önem vermiştir. Kuşkusuz bu bağı kuvvetlendiren en önemli unsurlardan biri, kulun rabbine ihlaslı bir şekilde yapmış olduğu ibadetleridir. Namaz ise, bu ibadetlerin en önemlisi olduğu için namaza hazırlık sayılan abdest ve teyemmüm de o derece önemli kabul edilmiştir.

Kur'ân-1 Kerim'de, abdest ve teyemmüm konuları, Mâide sûresi 6. ve Nisâ sûresi 43. âyetlerde müstakil olarak ele alınmıştır. İslâm âlimlerinin bu iki âyeti anlamaya yönelik ortaya koydukları emek ve gayret neticesinde birçok yorum ve ictihâd ortaya çıkmıştır.

Bu iki âyet çerçevesinde ortaya çıkan en önemli ihtilaflardan biri, karşı cinse dokunmanın abdesti veya teyemmümü bozup bozmadığ konusudur. Şöyle ki; bahsi geçen âyetlerde, abdest ve teyemmüm alınmasi gereken durumlardan biri olarak zikredilen “.... أو لامستم النساء (ev lâmestumu'n-nisâe/ya da kadinlara dokunduğunuzda)...” ifadesi ile ne kast edildiği hakkında, ilk dönemden (asr-1 saâdetten) günümüze kadar süre gelen birçok ihtilaf söz konusu olmuştur. Bazı âlimler, “.... أو لامستم النساء (ev lâmestumu'n-nisâe)...” ifadesinden kast edilen mananın mutlak dokunmak, bazıları şehvetle dokunmak, bazıları ise mecazî anlamda cinsel birliktelik (cimâ) olduğunu söylemişlerdir. Bu farklı anlamlandırmalara bağlı olarak, bir kısım âlimler, "karşı cinse mutlak anlamda dokunmak"; bir kısmı, "sadece şehvetle dokunmak"; bir kısmı da, "kadınlarla cimâda bulunmak" abdesti ve teyemmümü bozar şeklinde ictihâda varmışlardır.

Çalısmada, Sünnî olmayan Şî̂-Caferî, Şî̀-Zeydî ve Haricî-İbâzî mezheplerinin, ilgili âyetler bağlamında "lems/mülâmese" konusu hakkındaki görüşleri, görüşlerini dayandırdıkları aklî ve naklî deliller ve de kendi görüşlerini savunma sadedinde karşıt görüşteki âlim ve mezheplere vermiş oldukları cevaplar, mümkün mertebe temel kaynaklara başvurulmak suretiyle ortaya konulmuştur.

Konuyu ele alırken ilk olarak, zikredilen âyetlerde yer alan "lemese/lâmese" kelimelerinin önemli bazı klasik sözlüklerde (mu'cemler), Ğarîbu'l-Kur'ân türü eserlerde ve tefsir kaynaklarında hangi manada kullanıldıklarına, ilgili âyetlerin kırât farklılklarına, bu farklılıkların müfessirler ve fakihler tarafindan nasıl değerlendirildiklerine ve manaya olan etkilerine temas edilmiştir. Ardından ilgili âyetler (el-Mâide 5/6, en-Nisâ 4/43) ve hadîsler mealleriyle zikredilmiş ve Sünnî olmayan mezheplerin görüşlerine dayanak teşkil etmeleri açısından kısaca değerlendirilmişlerdir. Bu çerçevede, hadîs usulü anlayışı diğerlerine göre farklı olan Caferîlerin hadîs/rivâyet kavramına yaklaşımlarına da kısaca yer verilmiştir.

Yukarıda yapılan ön bilgi mahiyetindeki açılamalardan sonra, Sünnî olmayan mezheplerin lems/mülâmese konusundaki görüşleri ve delilleri ayrıntılı olarak ortaya konulmuş ve şu bulgulara varılmıştır:

Şîi-Caferîler, başta hadîs usulü anlayısları ve mezhep içi bazı muhafazakâr tutumları sebebiyle, lems/mülâmese konusunu özellikle ilk dönemlerde sadece ehl-i beytin masum imâmlarından gelen rivâyetlerle açılamaya çalışmışlardır. o kadar ki, ne birçok sahabe ve tabiînden gelen rivâyetlere (naklî delillere) yer vermişler, ne de aklî ve lugavî delillere başvurma gereği duymuşlardır. Bu bakımdan, diğer mezheplere göre oldukça farklı ve/veya korumacı bir yaklaşım tarzı sergilediklerini söylemek mümkündür. Ne var ki, Caferîlerin, tarihsel süreçte mülâmese konusunu ele alırken mezhep içinde farklıyöntemler sergiledikleri de görülmüştür. Söz gelimi, Şî̀-Caferîlerin, Ahbârîlik geleneğine 
mensup ilk dönem âlimleri, konuyu sadece ehl-i beytin masum imamlarından gelen rivâyetler ışığında anlamışlar; bu rivâyetler dışında başka bir delile başvurmaya ise şiddetle karşı çıkmışlardır. Buna karşllık daha sonraki dönemlerde ortaya çıkan Usûlîler (ve özellikle hicri 6. asır âlimi Tabersî) ise, masum imamlardan gelen rivâyetler yanında, birçok sahabe, tabiîn ve sünnî âlimlerden gelen rivâyetleri ve de aklî ve lugavî delilleri de dikkate almışlardır. Sonuçta Caferîler, ilgili âyetlerde yer alan “.... أو لامستم النساء (ev lâmestumu'n-nisâe)...” ifadesinin, imamlardan gelen rivâyetler ışı̆̆ında, mecâzî anlamda cinsî münasebet (cimâ) olduğu görüşünü kabul etmişler. Bu sebeple de, mahrem veya nâmahrem olduklarına bakılmaksızın karşı cinslerin -birbirini öpmeleri de dâhil- birbirine dokunmalarının hiçbir şekilde abdesti bozmayacağını savunmuşlardır. Bu görüş hususunda mezhep içinde ihtilaf olmadığı ve hatta ittifak (icmâ) olduğu da söylenmiştir.

Şîi-Zeydîler, lems/mülâmese konusunda istidlalde bulunurken, Caferîlerden farklı olarak, sadece ehl-i beyt imamlarından gelen rivâyetlere değil, aynı zamanda Şî̂lerin dışındaki mezheplerce muteber sayılan kaynaklarda yer alan birçok hadîs ve rivâyete de yer vermişlerdir. Yine, Caferîlerin aksine, görüşlerini aklî ve lugavî delillerle de destekleme yoluna gitmişlerdir. Bu sebeple Zeydîlerin mülâmese konusunda nispeten daha mutedil davrandıkları söylenebilir. Zeydîler, “.... أو لامستم النساء (ev lâmestumu'n-nisâe)..." ifadesinden maksadın, başta ehl-i beyt ve diğer birçok sahabe, tabiîn ve imamlar yoluyla gelen rivâyetlere göre, mecâzen cinsel birliktelik olduğunu belirtmişlerdir. Bu itibarla onlar, erkek ve kadınların, mahrem veya nâmahrem olmalarını dikkate almadan, birbirine dokunmalarının hiçbir şekilde abdesti bozmayacağı görüşünü benimsemişlerdir.

Harici-íbâzîler ise, ilk dönemlerde kaleme aldıkları eserlerinde, abdesti bozan durumları zikrederken daha çok necâsetin çıkması ve günah işlenmesi üzerine yoğunlaşmışlardır. Bu sebeple karşı cinse dokunmanın abdeste etkisini özel olarak ele almadıkları görülmüştür. Dolayısıyla ilgili âyetlerdeki “.... أو لامستم النساء (ev lâmestumu’n-nisâe)...” ifadesinin, hakikî veya mecâzî olmasına pek fazla değinmemişlerdir. Ancak başta Me 'aricu'l-A'mâl olmak üzere son zamanlarda telif ettikleri eserlerinde mülâmese konusuna oldukça yer ayırdıkları görülmüsstür. Şu halde İbâzîlere göre, ilgili âyetlerde yer alan lemese/lâmese kelimeleri, mecâzî anlamda cinsel birliktelik olduğu için, mahrem veya nâmahrem olduğuna bakılmadan karşı cinse mutlak olarak dokunmak abdesti bozmaz. Bununla birlikte günah kabul edilen her türlü kötü söz ve davranışın abdesti bozacağını savunmaları sebebiyle, kadının haram olan avret mahalline (el ve yüz hariç bütün vücuduna) bakmanın veya dokunmanın yahut da bakmanın haram olmadığı yerlere şehvetle bakmanın ve dokunmanın abdesti bozacağını söylemişlerdir. Ayrıca onların bu konuda, görüşlerini destekleyen hemen her hadîsi/rivâyeti, sahih olup olmadığı ayırımı yapmaksızın delil olarak kullandıkları da görülmüsşür.

\section{Anahtar Kelimeler}

İslâm Hukuku, Caferî, Zeydî, İbâzî, Abdest, Dokunma

\section{Giriş}

İslam dininde kul ile yüce yaratıcısı arasında bağların güçlü ve sürekli olması hedeflenmiştir. Bu bağların en önemli tezahürü hiç şüphesiz kulun rabbine ibadette bulunmasıdır. İbadetler yüce yaratıcının önünde eğilmek ve azametini kabul etmek anlamına geldiği için her inanç sisteminde belli kurallar çerçevesinde gerçekleşmektedir. İslâm dininde insanın her açıdan temizlenme vesilesi kabul edilen ibadetlerin başında namaz gelir. Öyle ki, İslâm'da kelime-i tevhitten sonra en önemli ibadet namaz kabul edilmektedir. Nitekim Hz. Peygamber'in de, bazı hadîslerinde namazdan, Müslümanları kâfir ve münafiklardan ayırt edici işaret olarak bahsettiği görülür. Bununla birlikte namaza hazırlık için yapılan

1 Bu konuda Hz. Peygamber şöyle buyurmuştur: "Müslüman ile şirkve küfür arasındaki farknamazı terketmektir". Bk. Ebu'l-Huseyn b. el-Haccâc Müslim, Șahị̂̂ Müslim, tḥk. Muhammed Fuâd Abdulbâkî(Beyrut: Dâru İhyâi't- 
bir takım temizlikler anlamındaki abdest de -aynen namaz gibi-Kur'ân ile düzenlenmiştir. Şu halde abdestsiz namaz kılınamayacağından dolayı abdest, namaz kadar önemli kabul edilmiştir.

Kur'ân-1 Kerîm'de, namaz kılmaya kalkacak olan kimsenin hangi durumlarda abdest alması gerektiği Mâide 6. ve Nisâ 43. âyetlerde ifade edilmiştir. Ne var ki, birçok fikhî meselede olduğu gibi bunda da tafsilata dair hususlar Hz. Peygamber'in söz, fiil ve davranışlarına bırakılmıştır. Bunun bir neticesi olarak da abdesti bozan durumlar, başka bir deyişle abdest alınması gereken durumlar, Hz. Peygamber'in uygulamalarında (sünnette) etraflıca ele alınmıștır.

Abdest her ne kadar maddî bir temizlik gibi görülse de insanın gün içinde yapmış olduğu bazı günahlarını da silip attığı ve sadece maddî kirlerden arındırmaktan ibaret olmadığı için manevî yönü ağır basan bir temizlik kabul edilir. ${ }^{2}$ Bu sebeple maddî pisliklerin bulunması durumunda abdest alınmasının gerekli olacağı hususu aklen kavranılması kolay ve mümkün olduğundan fikıh mezhepleri arasında pek fazla ihtilafbulunmamaktadır. ${ }^{3}$

Türâsi'l'-'Arabî, ts), “Îmân”, 134; Süleymân b. el-Eş'as es-Sicistânî Ebû Dâvûd, Sünenü EbîDâvûd, tḥk. Muhammed Muhyiddîn Abdulhâmid (Beyrut: el-Mektebetü'l-'Asriyye, ts.), "Sünnet", 15. Başka bir hadîste Efendimiz: "Bizimle münafiklar arasındaki fark namazdır" buyurmaktadır. Bk. Ebû İsâ Muhammed b. İsâ b. Sevre İbn Mûsâ et-Tirmizî, Sünenü't-Tirmizî, tḥ̂. Ahmed Muhammed şâkir (Kahire: y.y., 1357/1938), "Îmân”, 9; Nesâ̂,, "Salât", 8. Sünnî düşüncede, amel imandan bir cüz kabul edilmediği için bu tür rivâyetler, ibadetlerin terkinden dolayı Müslümanların gayrimüslimlere benzetilerek imanın zayıflaması şeklinde te'vîl edilmiştir. Bk. Ebû Hâmid Muhammed b. Muhammed el-Gazâlî, el-ikttisâad fil-I'tikạad (Cidde: Dâru'l-Minhâc, 2. Bask1, 1433/2012), 284, 285; Ebû Hafs Sirâcuddîn Ömer b. İshâk el-Gaznevî, Șerhu 'Akîideti'ț-Tahaviyye, tḥk. Hâzim Geylânî el-Hanef - Muhammed Abdulkâdir Nassâr (Misır: Dâru'l-Kerez, 2009), 115, 116.

2 Abdestin manevî temizlik olduğu hususunda Hz. Peygamber şöyle buyurmuştur: "Her kim namaz kılmak amacıyla abdest almaya kalkar da ellerini yıkarsa, ilk damlayla beraber elleriyle yaptığı günâhlar akar gider. Ağzına su verip çalkaladığında diliyle ve dudaklarıyla işlediği günâhlar, akan ilk su damlasıyla beraber akar gider. Yüzünü, dirseklere kadar ellerini, topuklara kadar ayaklarını yıkadığı zaman da onlarla yaptığı her günâhtan kurtulur. Annesinden doğduğu gün gibi tertemiz olur". Bk. Müslim, "Tahâret", 32; Ebû Abdirrahmân Ahmed b. Şu'ayb b. Alî b. Sinân en-Nesâî, Sünenü'n-Nesâî (es-Suğrâ), tḥ̣k. Abdulfettâh Ebû Ğudde (Haleb: Mektebetu'l-Matbû'ati'l-islâmiyye, 1406/1986), "Tahâret", 58; Ebû Abdillâh Muhammed b. Yezîd el-Kazvinî İbn Mâce, Sünen, tḥk. Muhammed Fuâd Abdulbâkî (b.y.: Dâru'l-Fikr, ts.), "Tahâret", 6. Ayrıca abdest almaya devam eden kişilerin abdest uzuvları parlayacağı için ahirette, Efendimiz tarafindan hemen tanınacaktırlar. Nitekim bu hususta Hz. Peygamber bir kabristan ziyaretinde şöyle buyurmuştur: "Size selam olsun ey mü’ minler topluluğunun yurdu! Muhakkak biz de Allah dilerse size katılacağız. Biz kardeşlerimizi görmeyi arzu ederiz”. Yanında bulunan sahabîler: “Ey Allah’ın Resûlü biz senin kardeşlerin değil miyiz? diye sorunca Efendimiz: "Siz benim ashâbımsınız/arkadaşlarımsınız, kardeşlerim ise daha sonra geleceklerdir" şeklinde cevap vermiştir. Onlar; "Sonra gelecek ümmetini nasıl tanırsın yâ Resûlallâh?" diye sorunca, O şöyle buyurmuştur: "Ne dersiniz bir adamın siyah atların arasında alnı beyaz olan bir atı olsa, onu tanımaz mı?" deyince", "Tabiî ki tanı" diye onu tasdik ettiler. Bunun üzerine Resûlullâh şöyle buyurdu: "Onlar kıyâmet günü abdestten dolayı uzuvları beyaz ve parlak olarak gelirler de ben onları Kevser havuzuna sokarım". Bk. Müslim, "Cenâiz", 104.

3 Sözgelimi, bevl ve ğâitin abdesti bozduğu ittifak ile kabul edilmektedir. Buna karşllık bütün mezheplerde necis kabul edilen kan ve kusmuğun abdeste etkisi hususunda mezhepler arasında ihtilaf bulunmaktadır. Bk. Şemsuddîn Muhammed b. Ahmed el-Hatî̉b eş-Şirbînî, Mugini'l-Muhtâc ilâ Ma'rifeti Elfâzi'l-Minhâc (İstanbul: Matbaatu Eser, 1377/1958), 1/31-36; İbn Âbidîn, Seyyîd Muhammed Emîn b. Ömer b. Abdulazîz, Ḥ̂şsiyetu İbn Âbidîn (Reddü'l-Muhtâr 'ale'd-Dürril'-Muhtâr) (Beyrut: Dâru'l-Ma'rife, 2015), 1/ 284-294; Hüseyin Kahraman, "Hadislere Göre Kusmanın Abdeste Etkisi”, Uludağ Üniversitesi İlahiyat Fakültesi Dergisi 18/2 (2009), 152-182: Fatih Turay, “Kanın Abdeste Etkisi”, Atatürk Üniversitesi Illahiyat Fakültesi Dergisi 43 (2015), 422-439. 
Ne var ki, delâleti zannî bir nassın dilsel yorum farklılıkları sebebiyle, karşı cinse dokunma konusunda mezhepler/fukahâ arasında ihtilaf ortaya çıkmıştır.

Şu halde karşı cinse dokunma durumunda abdestin bozulup bozulmayacağı (lems/mülâmese) konusu abdeste dair en önemli ihtilaflarından biridir. ${ }^{4}$ Aşağıda da ifade edildiği üzere ülkemizde karşı cinse dokunmayla ilgili Sünnî mezheplerin görüşlerini ve delillerini ele alan makaleler yazılmıştır. Ancak konuyla ilgili olarak Sünnî olmayan mezheplerin görüşlerini ihtiva eden bir çalışmaya rastlanılmamıştır. Dolayısıyla bu makalenin ülkemiz itibariyle hem yeni hem de orijinal bir nitelik taşıdığı açıktır. Bu sebeple makalede, konunun, Şiîler ve İbâzîler tarafından nasıl ele alındığı irdelenmeye çalışılmıştır.

Başta tefsir, hadîs ve özellikle de mezheplerin temel fikıh kaynaklarında konuyla ilgili ihtilafin var oluş sebepleri ve boyutu, mezheplerin görüş ve delilleri, karşıt görüşlere verdikleri cevaplar ve konuya 1şık tutacak rivâyetler birçok yönden ele alınarak tahlil edilmiştir.

Karşı cinse dokunma (lems/mülâmese) konusu, Sünnî ya da Sünnî olmayan tüm tefsir kaynaklarında ilgili âyetlerin tefsirleri kısmında, hadîs ve fikıh eserlerinin temizlik kitabının (kitâbu't-țahâreh) alt başlikları olan abdesti bozan ve bozmayan şeyler (babu mâ yenkużul vużu ve mâ lâ yenkużuhu) kısımlarında detaylı bir şekilde ele alınmıştır. Şu halde konuyla ilgili olarak oldukça zengin bir literatür oluştuğu aşikârdır. Bubağlamda istifade edilen eserlere kaynakçada tek tek yer verilmiştir.

Ne var ki, konunun klasik metinlerde ayrıntılı olarak ele alındığını söylemek mümkün olmakla beraber bütün mezheplerin görüş ve delillerinin bir arada verildiği ve değerlendirildiği bütüncül bir çalışma yoktur.

Günümüzde yapılan çalışmalara gelince; abdest âyetini konu alan birkaç çalışmadan bahsetmek mümkün olmakla birlikte, bunların da, içerik ve kapsam açısından çalışmamızdan farklı olduğunu ifade etmek gerekir. Söz gelimi, "Hüseyin Kahraman, Hadislere Göre Karşı Cinse Dokunmanın Abdeste Etkisi, Uludağ Üniversitesi İlahiyat Fakültesi Dergisi 19/1 (2010), 69-109" künyeli makale bunlardan biridir. Yazar, çalışmasında mülâmesenin abdesti bozup bozmayacağı hakkında vârid olan bazı önemli hadîsleri farklı senedleri ile ele alarak sened ve sıhhat açısından değerlendirmeler yapmış ve satır aralarında bazı sahabî ve mezheplerin görüşlerine yer vermiştir. Başka bir ifade ile fikıh mezheplerinin görüşlerini ayrıntılı olarak ele almadığı, mezhep imâmının görüşünü vermekle beraber ilgili mezhepte muftâ bih görüşün tam olarak ne olduğunu belirtmediği için -başlıktan da anlaşılacağı üzere- fikhî çalışmadan ziyade hadîs çalışması niteliği taşımaktadır. ${ }^{5}$

4 Örneğin, Hanefilere göre sadece fâhiş mübaşeret abdesti bozar. Zira bu durumda necâsetin/mezinin çıkma ihtimali oldukça yüksektir. Kadınlara mutlak dokunmak abdesti bozar diyen İmâm şâfiî ve Zâhirîler ise bunun taabbudî olduğunu söylerler. Bk. Ebû Zekeriyyâ Yahyâ en-Nevevî, el-Mecmu' Şerhu'lMühezzeb, tḥk.-tlk. Muhammed Necîb Muțiî (Cidde: Mektebetu'l-İrşâd, ts.), 2/30. Nevevî, burada abdesti bozan şeylerin illetlerinin tam olarak tespit edilemediği için kıyasa kapalı olduğunu da söyler.

5 Söz konusu makalede, ilgili meseleye, fikıhçıdan ziyade hadisçi gözüyle bakıldığı için meselenin fikhî açıdan eksik olduğu görülmüştür. Örneğin yazar, bahsi geçen makalenin 72-74. sayfaları arasında, İmâm Şâfiî̀nin görüşünü aktarırken küçük veya büyük olduğuna bakılmadan yabancı kadına dokunmanın abdesti bozacağını ifade etmiştir. Oysa Nevevî, Şirbînî ve Büceyremî gibi önemli Şâfiî fikıhçılara göre mezhepte muteber (muftâ bih) görüş, sadece şehveti celp edecek yaşta olan kadınlara dokunmanın abdesti bozmasıdır. Daha fazla bilgi için bk. Nevevî, Ravżatu't-Tâlibîn (Beyrut: Dâru İbn Hazm, 1423/2002), 1/34; Süleymân b. Muhammed b. Ömer el-Büceyremî, el-Büceyremî 'ale'l-Hațîb (Beyrut: Dâru'l-Kütübi'l-İlmiyye, 
Diğer bir çalışma, “Emine Esin Göç, Lemsü’n-nisâ’nın Abdeste Etkisi Konusundaki Fıkhî Tartışmalar, Marmara Üniversitesi İlahiyat Fakültesi Dergisi 35/2 (2008), 73-90” künyeli makaledir. Bu makale, konu itibariyle çalışmamızla benzerlik arz etmekle beraber, Sünnî mezhepleri konu edinmesi ve dipnotlarında mezheplerin görüşlerini kendi kaynaklarından değil de, başka mezheplerin (karşılaştırmalı) fikhî eserlerinden aktarması sebebiyle çalışmamızdan farklılık göstermektedir.

Son çalışma ise, "Sahip Beroje, Fıkıh Açısından Karşı Cinse Dokunmanın Abdeste Etkisi, İslam Hukuku Araştırmaları Dergisi 30 (2017), 385-421” künyeli makaledir. Yazar çalışmasında Sünnî mezheplerin görüşlerini; delilleri ve deliller içerisindeki bazı hadîsleri değerlendirmeye çalışmıştır. Sünnî mezheplerin görüşlerini ve delillerini temel kaynaklardan yararlanarak etraflıca ele alma noktasından güzel bir çalışma olmakla beraber, bu çalışmanın da Sünnî mezheplere odaklanması itibariyle çalışmamızdan farklı olduğu görülmektedir.

Kısaca belirtmek gerekirse, karşı cinse dokunmanın abdeste etkisini ele almaları yönüyle çalışmamızla benzerlik arz eden bu makalelerde, mülâmese hakkında Sünnî hadîs kaynaklarında vârid olan hadîsler sened ve sıhhat açısından bir değerlendirmeye tâbi tutulmuş ve bu bağlamda Sünnî mezheplerin görüş ve delilleri ele alınmıştır. Çalışmamızda ise, Sünnî olmayan mezheplerin, "lemese (lems)" ile "lâmese (mülâmese)" terimlerinden hareketle karşı cinse dokunma konusuna yaklaşımlarına; görüşlerine, delillerine ve nihayet karşıt görüşteki mezheplere verdikleri cevaplara ayrıntılı olarak yer verilmiştir.

Çalışmamızda ilk olarak, lemese/lâmese'nin lugavî tahlîline ve kıraât farklılıklarına değinilmiştir. Ardından lems/mülâmese konusunu düzenleyen âyet ve hadîslere yer verilmiştir. Daha sonra çalışmamızın temelini teşkil eden, Sünnî olmayan mezheplerin konu ile ilgili görüş ve delilleri detaylı bir şekilde ele alınarak değerlendirilmiştir.

\section{Lemese/Lâmese'nin Lugavî Tahlîli ve Kıraât Farklılıkları}

\subsection{Lemese/Lâmese'nin Lugavî Tahlîli}

Lemese (lems) ve lâmese (mülâmese) kelimelerinin terim manası çerçevesinde ortaya çıkan fikhî ihtilafların en önemli sebeplerinden biri, bu kelimelerin Arapça'da yaygın olarak "el ile dokunmak", "el ile yoklamak" ve "cinsel birliktelik" gibi farklı anlamlarda kullanıllyor olmasıdır. Bu nedenle Mâide sûresinin 6. ve Nisâ sûresinin 43. âyetlerinde yer alan "... أو لامستم ..." ifadesini daha doğru tahlil edilebilmek ve neticede doğru bir sonuca ulaşabilmek için, bu kelimelerin bașta klasik sözlükler (mu'cemler), Ğarîbu'l-Kur'ân türü eserler ve tefsir kitaplarında nasıl ele alındıklarını ve hangi manalarda kullanıldıklarını ortaya koymak gerekir. Bu sebeple, öncelikle bazı önemli dilcilerin ve müfessirlerin konuyla ilgili görüş ve izahlarinı aktarmak yerinde olacaktır.

1996), 1/311; Şirbînî, Muğni'l-Muhtâc, 1/34-36. Yine Hanefî mezhebinin görüş ve delillerini aktarırken mezhebin görüşü tam olarak verilmemiştir. Şöyle ki; Hanefillere göre, fâhiş mübaşeretin abdesti bozacağ1 ifade edilmiştir. Ancak bu mübaşeretin ne olduğu ve hangi durumlarda abdesti bozduğu hususuna değinilmemiştir. Hanefilere göre, fâhiş mübaşeret arada bir engel olmadan erkek ve kadının cinsel uzuvlarının birbirine değmesidir. Bu temas, İmâm Muhammed'e göre abdesti mutlak bozarken Ebû Hanîfe ve Ebû Yûsufa göre ise sadece necâsetin çıkması durumunda bozar. Hanefî imâmlar arasındaki bu ihtilafa bakıldı̆̆ında, fâhiş mübâşeret durumlarında abdesti bozan şeyin, necâsetin bilfiil çıkması veya fâhiş mübâşeretten dolayı necâsetin çıkma ihtimalinin yükssek olmasıdır, denilebilir. Daha fazla bilgi için bk. Alâuddîn Ebû Bekr b. Mes'ûd el-Kâsânî, Bedâiu's-Sanâi' fî Tertîbi'ş-Şerâi' (Beyrut: Dâru'l-Kütübi'l-İlmiyye, ts.), 1/243-247; İbn Âbidîn, Hâşsiyetu İbn Âbidîn, 1/303-304. 
Cevherî(öl. 393/1003), eș-Șihâh Tâcü'l-Luġa ve Șihâhu'l-'Arabiyye adlı eserinde, söz konusu her iki ifadenin "el ile dokunmak" ve kinaye yoluyla "cimâ" anlamında kullanıldıklarını ifade etmiştir. ${ }^{6}$

Râğıb el-İsfehânî (öl.559/1164), en önemli Kur'ân sözlüklerinden sayılan, el-Müfredât fí Garîbi'l-Kur'ân adlı eserinde, lâmese ve lemesenin; "el ile dokunmak", "el ile yoklamak" ve bazen mecâzî olarak "cimâ" anlamında kullanıldıklarını söylemiştir.

İbn Manzûr (öl. 711/1311), Lisânü'l-'Arab adlı eserinde, lemese ve lâmese kelimelerinin; “el ile dokunmak”, "el ile yoklamak”, “öpmek” ve mecâzen "cinsel birliktelik” anlamlarında kullanıldıklarını belirtmiştir. '̇̉bn Manzûr, bu kelimelerin aynı manada olduklarını bildirdikten sonra bazı âlimlerin, bu kelimeler arasında şöyle bir farktan bahsettiklerini aktarmıştır: "Lemese, bir şahsın bir nesneye dokunması veya nesnelerin birbirine dokunması anlamında kullanılır. Lâmese ise, sadece bireyler arasında gerçekleşen dokunmaları ifade eder". '̇ Ibn Manzûr, mezkûr açıklamalarının yanı sıra bu kelimelerin "mutlak dokunma" veya "cimâ" anlamında olduğunu kabul eden fakihlerin isimlerini vermeden delillerini Kur'ân-1 Kerîm, Sünnet ve sahabe kavlinden aktararak konuyu fikhî açıdan da k1saca ele almaya çalışmıştır. ${ }^{10}$

Fîrûzâbâdî (öl. 817/1415) ise, lemesenin; "el ile dokunmak" ve "cinsel birliktelik" anlamında; lâmesenin ise sadece "cimâ" anlamında olduğunu savunmuştur. ${ }^{11}$

Meşhur dilcilerin, söz konusu kelimeler hakkındaki görüşlerini aktardıktan sonra, konuyla ilgili bazı müfessirlerin görüşlerine de kısaca yer vermekte fayda vardır. Meselâ Ebû Alî el-Fadl b. Hasen et-Tabersî (öl. 548/1153) ile Şevkânî (öl. 1250/1834), lemese ve lâmesenin Arapça'da mutlak dokunma ve cimâ anlamlarında kullanıldıklarını, ancak ilgili âyetlerde cimâ kast edildiğini ifade etmişlerdir. Ayrıca Şevkânînnin aktardığına göre, büyük dilci ve müfessirlerden sayılan Ebu'l-Abbâs Muhammed b. Yezîd Muberred el-Ezdî (öl. 286/900); lemese kıraâtinin “öpmek", lâmese kıraâtinin ise "cinsel birliktelik" anlamında olması gerektiğini savunmuştur. ${ }^{12}$

Özetle diyebiliriz ki; dilcilerin çoğunluğu, lemese ve lâmese kelimelerinin her ikisinin "el ile dokunmak", "el ile yoklamak", “öpmek" ve mecâzen de "cimâ"” şeklinde aynı anlamda kullanıldıklarını kabul etmişlerdir. Bunun yanında bazı dilciler, lemesenin, şahısların nesnelere veya nesnelerin birbirine; lâmesenin ise, şahısların birbirine dokunmalarını ifade ettiğini söylemişlerdir. Yine bazı dilcilere göre lemese mutlak dokunma, lâmese

6 Ebû Nasr İsmấîl b. Hammâd el-Cevherî, eș-Ṣıhâh Tâcü'l-Luġa ve Șihâhu'l-'Arabiyye, tḥk. Ahmed Abdulğafûr 'Attâr (Beyrut: Dâru'l-ìlm ve'l-Melâyîn, 2. Basım, 1399/1979), 3/975.

7 Ebu'l-Kâsım el-Huseyn b. Muhammed Râğib el-İsfehânî, el-Müfredât fî Garîbi'l-Kur'ân, tḥk. Muhammed Seyyîd Keylânî (Beyrut: Dâru'l-Ma'rife, ts.), 454.

8 İbn Manzûr, Ebu'l-Fadl Cemâluddîn Muhammed b. Mukerrem el-Ifrıkî el-Mısrî, Lisânü’l-'Arab (Beyrut: Dâru Sadr, 1414), 6/209.

9 İbn Manzûr, Lisânü'l-Aarab, 6/209.

10 İbn Manzûr, Lisânü'l-'Arab, 6/209.

11 Necduddîn Muhammed b. Ya'kûb el-Fîrûzâbâdî, el-Kâmûsu’l-Muhît (Beyrut: Müessesetü’r-Risâle, 2005), $573,574$.

12 Ebû Alî el-Fadl b. Hasen et-Tabersî, Mecma'u'l-Beyân fî Tefsîri'l-Kurâan (Beyrut: Dâru'l-Murtezâ - Dâru'l'Ulûm, 1427/2006), 3/79; Muhammed b. Alî b. Muhammed eş-Şevkânî, Fethu'l-Kadîr el-Câmi'u beyne Fenneyi'r-Rivâyeh ve'd-Dirâyeh min İlmi't-Tefsîr (Beyrut: Dâru'l-Ma'rife, 1428/2007), 1/751. 
ise cimâ anlamındadır. Ne var ki fakihler, farklı kıraâtlerdeki bu kelimeleri farklı anlamlarda kullanmamışlardır. Şöyle ki, fakihler, lemese veya lâmese kıraâtlerinden tercih ettikleri kıraâti hangi manada kabul etmişlerse, diğerini de, bu kıraâtin anlamına hamletmiş ve her iki kıraâtin aynı manada olduklarını var saymışlardır. ${ }^{13}$

\subsection{Lemese/Lâmese'nin Kıraât Farklılıkları}

Mâide sûresi 6. ve Nisâ sûresi 43. âyetlerde yer alan “.... أو لامستم النساء (...” ifadesinin

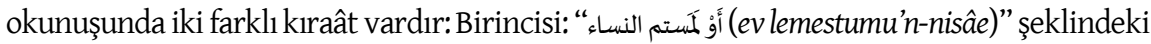
okumadır. Kıraât âlimlerinden Hamza b. Habîb (öl. 156/773), Alî b. Hamza el-Kisâî (öl. 189/805) ve Halef b. Hişâm el-Bezzâz (öl. 229/844) bu şekilde okumuşlardır. İkincisi: “... أو ألامستم النساء......ev lâmestumu'n-nisâe...)” şeklindeki kıraâttir. Hamza, Kisâî ve Halef dışındaki kıraât âlimleri bu şekilde okumuşlardır. ${ }^{14}$

Bu iki kıraât (lemese/lâmese), kıraât-1 seb'adan oldukları için bütün Müslümanlar tarafindan mütevâtir ve sahih kabul edilmiştir. Bu konuda icmâ vardır. ${ }^{15}$ Buna rağmen Caferî mezhebinde, "sadece ehl-i beyt imâmlarından sahih bir senedle gelen rivâyetler (k1raâtler) mütevâtir ve sahih kabul edilir" görüşü mevcut olsa da, bu ifadeler ile hangi imâm veya imâmların kıraâtinin kast edildiği açıkça anlaşılmamaktadır. Bu sebeple Şiî âlimlerin birçoğuna göre kıraât-1 seb'a sahih ve mütevâtir kabul edilirken ${ }^{16}$ bazıları ise, sadece senedinde Hz. Alî’nin yer aldığı Hafs rivâyetiyle gelen Âsım kıraâtini sahih ve mütevâtir kabul etmişlerdir. Hatta bazı Şiî âlimler, başta Ebû Bekr Âsım (öl. 127/745) olmak üzere Ebû ‘Amr b. A'lâ (öl. 154/771), Hamza ve Kisâînin de Şiî olduğunu iddia etmişlerdir. ${ }^{17}$

Zeydîler de, lemese ile lâmese kıraâtlerinden her ikisini kabul etmişlerdir. Söz gelimi Şevkânî, ilgili âyetleri tefsir sadedinde bu kıraâtlerin farklı manalarına temas etmiş, fakat haricî karinelerle cimâ anlamında buluştuklarını belirtmiştir. ${ }^{18}$

Mülâmese konusunda, mezheplerin görüşlerinin aktarıldığı başlıklarda da belirtildiği gibi, mevcut kıraât farklılıkları, âyetteki ifadenin, müfessirler tarafından farklı şekilde anlaşılmasına vesile olmuştur. ${ }^{19}$ Ancak bu farklılıklar, müfessirleri, söz konusu ifadeyi farklı şekilde tefsir etmeye sevk etmiş olsa bile, fikıhçılar mülâmeseyi hangi anlamda kabul

13 Bk. Ahmed b. Huseyn el-Hârûnî el-Hasenî, Şerhu't-Tecrîd fí Flkhi'z-Zeydiyye, tḥk. Muhammed Yahyâ Sâlim Ezân - Hâmid Câbir 'Âbid (San'a/Yemen: Merkezü't-Türâsi ve'l-Buhụsi'l-Yemenî, 1427/2006), 1/178; Şevkânî, Neylü'l-Evtâr Ş serhu Münteka'l-Ahbâr, tḥk. Ebû Mu'âz Târık (Riyâd: Dâru İbni'l-Kayyim - Kahire: Dâru İbn Affân, 1426/2005), 1/554; a.mlf., Fethu'l-Kadîr, 1/752.

14 Muhammed Hâdî Marifet, et-Temhîd fì 'Ulûmi'l-Kurân (Beyrut: Dâru't-Te âruf li'l-Metbû‘at, 1432/2011), 2/154; Ebû Ca'fer Muhammed b. Alîb. Hasen b. Alîet-Tûsî, et-Tibyânfí Tefsîri'l-Kur'ân (Beyrut: Dâru ihyâi'tTürâsi'l'-'Arabî, ts), 1/7; Muhammed Muhsin el-Feyd el-Kâşânî, Tefsîru's-șâfi (Meşhed: Dâru'l-Murtezâ, 2. Basım, 1402/1982), 1/53; Ebu'l-Hayr Muhammed b. Muhammed b. Alî b. Yûsuf İbnu'l-Cezerî, en-Neşru fi'-Krraâti'l-Așr (Beyrut: Dâru'l-Kütübi'l-Ilmiyye, ts), 2/250.

15 Marifet, et-Temhîd, 2/154.

16 Tûsî, et-Tibyân, 1/7; Kâşânî, Tefsiru'ṣ-Ṣâfi, 1/53; Marifet, et-Temhîd, 2/58.

17 Marifet, et-Temhîd, 2/143; Mustafa Öztürk, "İmâmiyye Şîası'nın Kıraat ve Ahruf-i Seba Anlayışı", Marife 8/3 (Kış 2008), 121-154, 134, 135.

18 Şevkânî, Fethu'l-Kadîr, 1/751.

19 Bk. Kâşânî, Tefsîru'ș-Ṣâfî, 1/358; Şevkânî, Fethu'l-Kadîr, 1/301, 302. 
etmişlerse diğer kıraâti de o manaya hamletmişlerdir. Bununla birlikte fikıhçılar, müfessirlerin kıraât farklılıklarından kaynaklanan farklı yorumlarını, kendi görüşlerini temellendirmek için delil olarak kullanmışlardır. ${ }^{20}$

\section{Konuyla İlgili Âyetler}

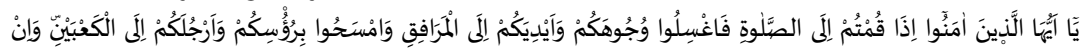

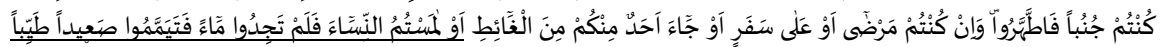

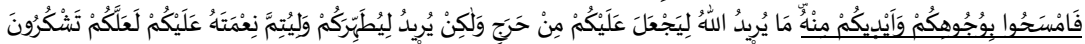
"Ey iman edenler! Namaza kalkacağını zaman yüzlerinizi, dirseklere kadar ellerinizi ve-başlarımızı mesh edip- her iki topuk kemiğinize kadar da ayaklarınızı yıkayın. Eğer cünüp iseniz, iyice ylkanarak temizlenin. Hasta olursaniz veya seferde bulunursanız veya biriniz abdest bozmaktan (def-i hacetten) gelir veya kadınlara dokunur (mülâmesede bulunur) da su bulamazsanız, o zaman (abdest veya gusül için) temiz bir toprağa yönelin. Onunla yüzlerinizi ve ellerinizi mesh edin (Teyemmüm edin). Allah, size herhangi bir güçlük çıarmak istemez. Fakat 0 , sizi tertemiz yapmak ve üzerinizdeki nimetini tamamlamak ister ki şükredesiniz". ${ }^{21}$

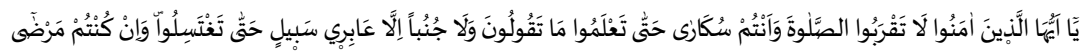

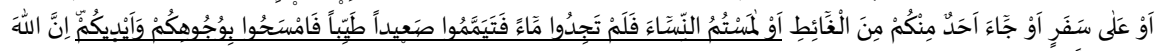

"Ey iman edenler! Sarhoş iken ne söylediğinizi bilinceye kadar, bir de -yolcu olmanız müstesna- cünüp iken yıkanıncaya kadar namaza yaklaşmayın. Eğer hasta olur veya yolculukta bulunursaniz veyahut biriniz abdest bozmaktan gelince ya da eșlerinizle mülâmesede bulunup, su da bulamazsanız zaman temiz bir toprağa yönelip, (niyet ederekonunla) yüzlerinizi ve ellerinizi mesh edin. Şüphesiz Allah, çok affedicidir, çok bağışlayıcıdır". ${ }^{22}$

Bu iki âyet, mülâmeseden doğrudan bahseder. Bu âyetlerin birincisi abdest alınması gereken durumları; ikincisi ise, teyemmümün meşruiyetini ve hangi durumlarda teyemmüm edilmesi gerektiğini izah etmek üzere nazil olmuştur. Dolayısıyla tefsir kaynaklarında ve özellikle ahkâm tefsirlerinde abdest ve teyemmüm âyeti olarak bilinirler. ${ }^{23}$

Sünnî tefsirlerde, el-Mâide 5/6'nın çalışmamızın ana temasını oluşturan lemese/lâmese (lems/mülâmese) kısmına odaklanılmıştır. Ancak Şiî-İmâmiyye müfessirlerinin (Caferîlerin) bu âyeti, mülâmeseden ziyade, abdestte ayakların meshinin caiz olup olmadığı hususuna yoğunlaşarak açıklamaya çalıştıkları görülür. Şöyle ki; bu âyette, “...başlarınızı meshedin...” emrinden sonra, “...ayaklarınızı da topuklara kadar (ve erculikum ile'l-ka'beyn)...” emri yer alır. Caferîler bu ifadeden, abdestte ayakların mesh edilmesi gerektiği anlamını çıkararak, Sünnîlere muhalefet etmişlerdir. Şu halde bu âyete, dokunma (lems/mülâmese) bağlamında yoğunlaşmadıkları anlaşılmaktadır. ${ }^{24}$

20 Bk. Ḥasenî, Şerḥu't-Tecrîd, 1/178; Şevkânî, Neylü'l-Evtâar, 1/554, 555; a. mlf., Fethuu'l-Ḳadîr, 1/752.

21 Kur'ân-ı Kerîm Meâli, çev. Halil Altuntaş - Muzaffer Şahin (Ankara: Diyanet İşleri Başkanlığı Yayınları, 2012), el-Mâide 5/6.

22 en-Nisâ $4 / 43$.

23 Muhammed et-Tâhir İbn ‘Âşûr, et-Tahrîr ve’t-Tenvîr (Tunis: Dâru't-Tûnisiyye, 1984), 5/66-67; Muhammed b. İsmâ'îl el-Emîr es-San'ânî, Sübülü’s-Selâm ilâ Şerhi Bulûgi’l-Merâm, tḥk.-tlk. Muhammed Nâsıruddîn elElbânî (Riyâd: Mektebetu'l-Ma ârif, 1427/2006), 1/193; Şerefuddîn Huseyn b. Ahmed b. Huseyn Haymî es-San'ânî, er-Ravżu'n-Nażîr Şerhu Mecmû'i'l-Fıkhi'l-Kebîr (Beyrut: Dâru'l-Cîl, ts.), 1/206.

${ }^{24}$ Daha fazla bilgi için bk. Kâşânî, Tefsîru'ṣ-Ṣâfî, 1/358; Şevkânî, Fetḥu'l-Kadîr, 1/301, 302. 


\section{Konuyla İlgili Hadîsler ${ }^{25}$}

عن عائشة رضي الله عنها أن النبي صلى الله عليه وسلم قبَّلَ بعضَ نسائه، ثم خرج إلى الصلاة ولم يتوضًَّاً

Hz. Âişe'den rivâyet edildiğine göre: “Hz. Peygamber hanımlarından birini öptü ve abdest almadan namaza gitti" ${ }^{26}$

Lemese/Lâmese'nin anlamlarından sadece öpmenin abdeste etkisini gösteren bu hadîs (Nebevî uygulama), Caferîler hariç, Sünnî olan ${ }^{27}$ ve olmayan ${ }^{28}$ birçok kaynakta yer almaktadır.

$$
\text { ولا المباشرة، ولا مس علي بن إبراهيم، عن أبيه، عن ابن أبي عمير، عن جميل، عن زرارة عن أبي جعفر عليه السلام قال: ليس في القبلة، }
$$

Alî b. İbrâhîm'in aktardığına göre, Ebû Cafer şöyle demektedir: "(Kadınl) Öpmeden, dokunmadan ve (kişinin kendi ya da eşinin) cinsel uzvuna dokunmasından dolayı abdest gerekmez". ${ }^{29}$

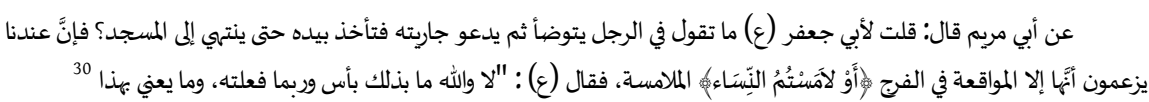

Ebû Meryem (öl.511/1190) şöyle dedi: “İmam Cafer [es-Sâdık(öl. 148/765)]'e: 'Adamın biri abdestini alır, cariyesini çağırır, cariyesi de elinden tutarak onu camiye ulaştırırsa bu adamın durumu nedir (abdesti bozulurmu)? Çünkü yakınımıda bulunan bazı kimseler (âyetteyer alan), “... أو .X... (ya da kadınlara dokunduğunuzda)" ifadesini kadına mutlak dokunma olarak anlarlar, ne dersiniz? diye sordum'. Ebû Cafer de: 'Hayır, vallahi kadına dokunmada (abdesti bozma hususunda) herhangi bir sakınca yoktur. Benim de öyle yaptığım (kadınlara dokunup abdest almadığım) durumlar olmuştur. Allâh, "ya da kadınlara dokunduğunuzda" ifadesiyle sadece cinsel münasebeti kastetmiştir' diye cevap vermiştir". ${ }^{1}$

25 Şî’nın hadîs/rivâyet anlayışı Sünnîlerden farklı olduğu için onlar Sünnîlerin kabul ettiği birçok rivâyeti kabul etmezler. Rivâyete dair bu yaklaşım farkllı̆ğına, her iki kesimin sahabeye bakış açııının etkisi olduğu açıktır. Şöyle ki; Şî'nın anlayışına göre, manen ehl-i beytten sayılan Hz. Selmân, Ebû Zerr ve Mikdâd gibi sahabîler hariç, başta ilk üç halife olmak üzere ashabın hemen hiç biri muteber değildir. Bu sebeple rivâyetlerini kabul ettikleri sahabe sayısı son derece azdır. Bk. Mahmut Demir, "Sahabe-Ehl-i Beyt Ekseninde Şî̀-Sünnî İhtilafının Hadis Rivayetine Yansımaları", e-Şarkiyat İlmî Araştırmalar Dergisi 6 (2011), 91-98. Ayrıca Şấ'da bir hadîsin/rivâyetin sahih olması için masum imâmdan aktarılması gerekir. O kadar ki, masum imâmlardan gelen hadîsler Hz. Peygamber'den rivâyet edilen hadîslerden daha çoktur. Bk. Cafer es-Sübhânî, Ușûlu'l-Hadî̀s ve Ahkâmuhu fîllmi'd-Dirâye (Lübnan: Dâru Cevâdi'l-Eimme, 1444/2012), 48, 50; Bekir Kuzudişli " "Şî̀'da Rivayet Olgusunu Şekillendiren Temel Unsurlar”, Dinbilimleri Akademik Araştırma Dergisi 18/1(2018), 61.

26 Ebû Dâvûd, "Tahâret”, 67; Tirmizî, "Tahâret", 63; Nesâ̂i, "Tahâret”, 121; İbn Mâce, "Tahâret”, 69; Ebû Abdillâh Ahmed b. Muhammed İbn Hanbel, Müsned, tḥk. Şuayb el-Arnavût - Âdil Mürşid (Beyrut: Müessesetü'r-Risâle, 1995), 6/210; Hasenî, Şerhu't'-Tecrîd, 1/177.

27 Mesela bk. Nesâî, "Tahâret”, 118; Alî b. Ömer ed-Dârekuțnî, Sünenü'd-Dârekuṭnî, tḥk..tlk. Şu'ayb el-Arnavût vd. (Beyrut: Müessesetü'r-Risâle, 2004), 1/245, 246.

28 Mesela bk. Ḥasenî, Şerhu't-Tecrîd, 1/177; Şevkânî, Neylü'l-Evțâr, 1/554-559; Nûruddîn b. Abdullâh b. Hâmid esSâlimî, Méâricu'l-A'mâl 'alâ Medârici'l-Kemâl (Bidiye/Ummân: Mektebetu'l-İmâm es-Sâlimî, 2010), 1/256.

29 Muhammed b. Ya'kûb el-Küleynî, el-Kâfi (Beyrut: Menşûrâtu'l-Fecr, 1428/2007), $3 / 37$ (Hadîs no: 12); Ebû Ca'fer Muhammed b. Alîb. Huseyn b. Mûsâb. Bâbeveyh el-Kummî, Men lâ Yahżuruhu'l-Fakîh (Beyrut: Müessesetü'l-Âlemî, 1406/1986), 1/50 (Hadîs no: 145); Tûsî, el-İstibșâr, tḥk. Seyyîd Hasen el-Mûsevî Horesân (Tahran: Dâru'l-Kütübi'l-İslâmiyye, 4. Basım, 1363), 1/87 (Hadîs no: 276).

30 Tûsî, el-İstibsâr, 1/87 (Hadîs no: 278).

31 Tûsî, Tehzîbu'l-Ahkâm fi Șerhi'l-Mukni' a, tḥk. Alî Ekber el-Ġafârî (Tahran: Dâru'l-Kütübi'l-ìslâmiyye, 1385), 1/22 (Hadîs no: 55). 
Sünnî olmayan mezheplerin kaynaklarında karşı cinse dokunmanın abdesti bozup bozmadığı hususunda birçok rivâyet bulunmaktadır. Fakat Sünnî olmayan mezhepler, bu tür dokunmanın abdesti bozmayacağı noktasında ittifak ettikleri için dokunmanın abdesti bozmadığını ifade eden rivâyetleri tercih ettik.

\section{Sünnî Olmayan Mezheplerin Konuyla İlgili Görüşleri ve Delilleri}

\section{1. Şî̀-Caferî (İmâmî) Mezhebi}

\subsubsection{Görüşleri}

Caferî mezhebine göre karşı cinslerin -birbirini öpmeleri dâhil- birbirine dokunmaları hiçbir şekilde abdesti bozmaz. ${ }^{32}$ Mezhebin en önemli furû fikıh kaynaklarından olan el-Mebsût fi Fikhi'l-İmâmiyye adlı eserde bu genelleme şöyle ifade edilir: "Mülâmesenin abdesti bozması hususunda dile getirilen hiçbir ihtilaf, bizim mezhebimizde geçerli kabul edilmez. Bu sebeple erkeğin küçük-büyük, mahrem veya nâmehrem kadına dokunması; kadının kadına dokunması; erkekle kadından birinin hünsaya ya da hünsaların birbirine dokunması abdesti bozmaz" ${ }^{33}$ Bu hususta Caferî mezhebinde icmâ olduğu kabul edilir. ${ }^{34}$ Muhtemelen bu sebepten olacak ki, bazı Caferî temel fikıh kaynaklarının abdesti bozan veya bozmayan şeyleri ele alırken karşı cinse dokunmanın hükmünü bazen çok kısa olarak ele aldıkları, bazen de buna hiçbir şekilde değinmedikleri görülür. ${ }^{35}$

Deliller başlığı altında da görüleceği üzere Caferî mezhebinin temel tefsir, hadîs ve fikıh kaynaklarında, mülâmese hususunda vârid olan neredeyse bütün hadîs ve rivâyetlerde mülâmesenin abdesti bozmayacağına dair bilgiler yer alır. Bunun aksini ifade eden ve "kadını şehvet ile öpme veya kadının cinsel uzvuna dokunma durumunda abdest alınması gerektiğini” ${ }^{\prime 3}$ ifade eden rivâyet ise, mezhep içerisinde genelde zayıf kabul edilmiş veya bu emir müstehâb olmaya hamledilmiş ya da (abdest almanın) "el yıkama" anlamında olduğu kabul edilmiştir. Yukarıdaki rivâyet, masum imâmlardan gelen rivâyetlere nazaran çok zayıf kaldığı için mezhep içinde herhangi bir ihtilafın ortaya çımasına yol açmamıştır. ${ }^{37}$ Nitekim söz konusu rivâyetler, deliller kısmında detaylı olarak ele alınmıştır.

\subsubsection{Delilleri}

Caferîlerin bu husustaki delilleri, Sünnî mezheplerden veya kendileri dışındaki Sünnî olmayan mezheplerden oldukça farklıdır. Caferîler, ilgili âyetlerin “... أو لامستم النساء...” kisminda yer alan mülâmeseyi sadece masum imâmlardan gelen rivâyetler ışığında ele almışlardır. Zira onlar, “Kur’ân-ı Kerîm’in ehl-i beyte indiği, onu hakkıyla anlamanın ancak

\footnotetext{
32 Tûsî, el-Mebsût fî Fıkhi'l-İmâmiyye (Beyrut: Dâru'l-Kitâbi'l-İslâmiyye, ts.), 1/26; Kâşânî, Tefsîru'ṣ-Ṣâfi, 1/358; Tûsî, Tehzîbu'l-Ahkâm, 1/20, 22, 23, 24 (Hadîs no: 47, 53-59).

33 Tûsî, el-Mebsût, 1/26.

34 Muhammed b. Alî el-Mûsevî el-'Âmilî, Medâriku'l-İhkâm Şerhu Şerâi'i'l-İslâm, tḥk. Müessesetü Âl-i Beyt li İhyâi't-Türâs (Meşhed/Îrân: Müessesetü Âl-i Beyt li İhyâi't-Türâs, 1 Basım, 1410), 1/151.

35 Örneğin, İmâmiyye mezhebinin hicrî 3. asrın önemli âlimlerinden sayılan İsmâ‘îl b. Mûsâ b. Ca fer, mezhebin önemli kaynaklarından olan el-Cáferiyyât/el-Eșǵasiyyât adlı eserinde, abdesti bozan hususları maddeler halinde ele alırken mülâmeseye hiç değinmiyor. Daha fazla bilgi için bk. İsmân̂l b. Mûsâ b. Ca‘fer el-Mezfer, Ca‘feriyyât, tḥk. Muştâk Sâlih (Kerbelâ: Isdâru Şu'beti’t-Tahkîk, 1434/2013), 29, 30.

36 Tûsî, el-İstibsâr, $1 / 88$.

37 Tûsî, el-İstibsâr, 1/88.
} 
onlara özgü olduğu" ${ }^{\text {"38 }}$ kanaatini taşımaktadırlar. Bu anlayışlarından dolayı birçok hususta olduğu gibi, bu hususta da delillerinin hemen hepsini ehl-i beyt imâmlarından gelen rivâyetler oluşturur. Şimdi Caferîlerin, görüşlerini dayandırdıkları delillere yer verelim:

1) Ebû Meryem şöyle dedi: “İmâm Cafer'e: 'Adamın biri abdestini alır, cariyesini çağırır, cariyesi de elinden tutarak onu camiye ulaştırırsa bu adamın durumu nedir (abdesti bozulur mu)? Çünkü yakınımızda bulunan bazı kimseler (âyette yer alan), “... ...... أو لامستم النساء ifadesini kadına mutlak dokunma olarak anlarlar, ne dersiniz? diye sordum'. Ebû Cafer de: 'Hayır, vallahi kadına dokunmada (abdesti bozma hususunda) herhangi bir sakınca yoktur. Benim de öyle yaptı̆̆ım (kadınlara dokunup abdest almadiğım) durumlar olmuştur. Allâh, '... أو لامستم النساء '...' ifadesiyle sadece cinsel münasebeti kast etmiştir' diye cevap vermiştir". ${ }^{39}$

2) Ebû Cafer: "(Kadını) Öpmeden, dokunmadan ve (kişinin kendi ya da eşinin) cinsel uzvuna dokunmasindan dolayı abdest gerekmez". ${ }^{40}$

3) Ebû Cafer: "Mülâmeseden maksat cimâdır; Allah hayâ sahibidir. Cimâ yerine dokunma ifadesini kullanmıştır". ${ }^{41}$

4) Abdullâh el-Halebî (öl. 2. asrın sonları), "Ebû Abdîllah (Cafer es-Sâdık)'a (kadını) öpmenin abdesti bozup bozmadığın sordum. 0 da, "hayır bozmaz' dedi” demiştir. ${ }^{42}$

5) Tabersînnin aktardığına göre; ilgili âyetlerin, “... أو لامستم النساء "...” kısmı hakkında Araplar ve mevâlîler arasında ihtilaf çıkmıştır. Araplar bunun mutlak dokunma; mevâlîler ise, cinsel birliktelik olduğunu savunmuşlardır. Bu tartışmanın yankısı, Kur'ân'ın tercümanı olan İbn Abbâs’a ulaşınca o, "Mevâlîler Araplara galip geldi” demiştir. Bu durum lâmesenin cimâ anlamında olduğuna delil gösterilmiştir. ${ }^{43}$

Esasında bu son rivâyet, Sünnîlerin ve özellikle Hanefillerin konuyla ilgili olarak gösterdikleri deliller arasında da yer almaktadır. ${ }^{44}$ Fakat bu rivâyet Caferîlerin temel klasik metinlerinde yer almaz. Ne var ki, hicrî 6. asırda Caferîlerin önemli tefsir ve fikıh âlimlerinden olan Tabersî, Mecma'u'l-Beyân fî Tefsîri'l-Kur'ân adlı eserinde buna yer vermiştir.

Yukarıda da ifade edildiği gibi, Caferîler bu meseleyi ehl-i beytten gelen rivâyetler 1şı̆̆ında ele almışlar ve bu sebeple de aklî ya da lugavî delillere başvurma gereği duymamışlardır. ${ }^{45}$ Caferîlerin temel kaynaklarında mesele, uzun müddet, ehl-i beyt imâmlarından gelen rivâyetlerle/naklî delillerle izah edilmeye çalışılmıştır. Ancak Tabersî, bu ve

38 Kâşânî, Tefsîru'ṣ-Ṣâfi, 1/9, 10.

39 Tûsî, Tehzîbu'l-Ahkâm, 1/22 (Hadîs no: 55).

40 Küleynî, el-Kâfî, 3/37 (Hadîs no: 12); Kummî, Men lâ Yahżuruhu'l-Fakîh, 1/50 (Hadîs no: 145); Tûsî, Tehzîbu'lAhkâm, 1/22 (Hadîs: no: 54).

41 Kâşânî, Tefsîru'ṣ-Ṣâfi, 1/358; Âkâ Huseyn et-Tebatabâî el-Burûcerdî, Câmi u Ehâdî̀si’ş-Şî́a (Kum: Matbaatu'lİlmiyye, 1399), 1/375, 376.

42 Tûsî, Tehzîbu'l-Ahkâm, 1/23 (Hadîs no: 58).

43 Tabersî, Mecma'u'l-Beyân, 3/79. Bu delil, mülâmesenin abdesti bozmayacağını söyleyen sünnî âlimlerin de kullandıkları önemli delillerden sayılır. Ancak ilk dönem Şîa kaynakları bu delile yer vermemiştir.

44 Ebû Bekr Ahmed b. Alî er-Râzî el-Cassâs, Ahkâmu'l-Kur'ân (Beyrut: Dâru İhyâi't-Türâsi'll-'Arabî, 1412/1992), 3/96-100.

45 Şîa'nın inancına göre; Kur'ân-1 Kerîm ehl-i beyte nazil olmuş, en ince ayrıntısına kadar bütün manası Hz. Peygamber tarafından Hz. Alî’ye öğretilmiş ve Hz. Alî̀den sonra da bu bilgiler, masum imâmlara intikal etmiştir. Bu sebeple bir âyetin tefsiri hakkında ehl-i beytin masum imâmlarından gelen bir rivâyet varsa mutlak doğru kabul edilir. Kâşânî, Tefsîru'ș-Ṣâfî, 1/19-22. 
benzeri birçok konunun sadece ehl-i beyt imâmlarından gelen rivâyetlerle savunulmasının yetersiz olduğunu ve yapılan eleştirilere ikna edici cevap verilemediğini düşünerek Caferîlerin görüşünü naklî delillerin yanında aklî delillerle de savunmaya çalışmıştır. Şöyle ki, o; ilgili âyetlerde geçen “.... أو لامستم النساء ...” ifadesiyle ilgili aktarılan görüşleri naklettikten sonra, "cimâ"” anlamının kast edilmesini isabetli bulmuş ve bunu, şu aklî ve lugavî delillerle izah etmeye çalışmıștır: 1) Abdest âyeti olarak bilinen Mâide sûresinin 6. âyetinde, suyun varlığı söz konusu olduğunda cünüp olma durumunda yıkanmadan namaz kılınmaması gerektiği anlatılmıştır. Nisâ sûresinin 43. âyetinde ise, suyun yokluğu durumunda teyemmüm emredilmiştir. Eğer teyemmüm âyetinde yer alan “... أو لامستم النساء kısmı cünüp olma durumu olarak kabul edilmezse suyun yokluğu durumunda cünüp olan kişinin hükmü anlatılmamış olacak ki, bu kabul edilemez; çünkü hükümlerin beyanı ihmal edilemez. Bu sebeple teyemmümü meşru kılan âyetin, “.... أو لامستم النساء i..." ifadesinden maksadın cinsel münasebet olması gerekir. 2) Yine âyet-i kerîmelerin ilgili kısımları ister "lemestum", isterse "lâmestum" şeklinde okunsun her ikisi de cinsel birliktelik anlamına gelir. O kadar ki, birinin sülâsî mücerred, diğerinin ise mufâ‘ale/muşâreke siygasılyla gelmiş olması durumu değiştirmez; zira dokunma iki kişi arasında gerçekleşir. Bu, Arapların yağmura gökyüzü (semâ) demelerine benzer. Çünkü nasıl ki, yağmur gökten yağdığı için yağmura gökyüzü demişlerdir; aynen bunun gibi, âyetlerde geçen ve cinsel birlikteliğin aracı ve öncüsü olduğu kabul edilen cimâya da dokunma (mülâmese) denilmiştir, ${ }^{46}$ şeklinde yorumlar yapmiştır.

Caferîler, klasik kaynaklarında, önceleri, kendileri ile aynı görüşü paylaştıkları görülen Hanefî ve diğer bazı Sünnî mezhep ve âlimlerin esas aldıkları onlarca hadîse, rivâyete ve aklî delillere/yöntemlere yer vermemişlerdir. Bunun iki önemli sebebinin olduğu söylenebilir. Birincisi; Caferîlerde, ehl-i beyt imâmlarının masum ve Kur'ân-1 Kerîm'i hakkıyla anlamaya sadece onların muktedir olmaları düşüncesinin hâkim olması ve bu sebeple de, onlardan gelen rivâyetlerin, konunun anlaşılması için yeterli kabul edilmesidir. İkincisi ise, Sünnîlerin bu hususta kullandığı hadîslerin çoğunun, kendilerinin sika kabul etmediği isimlerden rivâyet edilmiş olmasıdır. Anlaşılan Caferîler, hadîs anlayışlarındaki farklılıktan dolayı ortaya koydukları muhafazakâr tutumları sebebiyle, Sünnî râvîleri güvenilir kabul etmemektedirler. Fakat zamanla rivâyeti merkeze alan Ahbârîler yanında akla ve kıyasa önem veren Usûlîlerin ortaya çıkmasıyla bazı Caferî âlimlerin, içe dönük bu bakış açısından uzaklaştıklarını söylemek mümkündür. Nitekim mesela Tabersî̀nin görüşlerinde ve bir kısım çağdaş Caferî âlimlerin makale ve fetvalarında, Sünnîlerin naklî delillerine ve aklî yöntemlerine başvurduklarını görmekteyiz. ${ }^{47}$

46 Tabersî, Mecma'u'l-Beyân, 3/79.

47 Tabersî, Mecma'u'l-Beyân, 3/76-79. Tabersî söz konusu tefsirinde, klasik Şîa anlayışından farklı olarak, Sünnî rivâyetleri kullandığı gibi Arapçanın inceliklerine vakıf olan herkesin Kur'ân-1 Kerîm'in mücmel olmayan âyetlerini anlayabileceğini de savunur. Bu konuda bazı değerlendirmeler için bk. Mustafa Kâzım Yılmaz, “Mecmau'l-Beyân”, Türkiye Diyanet Vakfi İslâm Ansiklopedisi (Ankara: TDV Yayınları, 2003), 28/257. Ayrıca çağdaş araştırmacilardan Muhammed Sankur eş-Şeyh'in, karşı cinse dokunmak abdesti bozar mı sorusuna cevaben kaleme aldığı makalesinde başta Hanefîler olmak üzere kendileri ile aynı görüşte olan diğer Sünnî mezheplerin neredeyse tüm delillerini kullandığı görülmektedir. Bk. Muhammed Sankur eş-Şeyh, “Messu'lMer'eti lâ Yankużu'l-Vużûe inde'l-İmâmiyye", Huda'l-Kur'ân (Erişim 17 Ekim 2019). 


\subsection{3. İtirazlara/Karşıt Görüşlere Verdikleri Cevaplar}

Caferîlerin, karşı cinse dokunmanın abdesti bozmayacağına, ilgili âyet-i kerîmelerin “.... if if i... ifadesinden cimâ kast edildiğine dair ehl-i beytin masum imâmlarından gelen rivâyetlerin sıhhatine tartışmasız inandıkları için başka delillere ihtiyaç duymadıklarını az önce belirtmiştik. Bu düşünce ile muhalif olan görüşleri geçersiz saydıklarından, onlara aklî istidlallerle cevap verme ihtiyacı hissetmemişler ve Şî'nın temel kaynaklarında ehl-i beyt yoluyla gelen rivâyetlere ters düşen rivâyet ve görüşlerin de hiçbir kıymetinin olmadığını ifade etmişlerdir. ${ }^{48}$ Caferîlerde hemen her konuda ortaya konulan masum imâmlara teslimiyet yaklaşımı, bu hususta da geçerlidir.

Caferîlerde genel kabul bu olmakla birlikte, mezhebin önemli fikıhçılarından Tabersî, Caferî mezhebinin bu konudaki görüşlerinin ehl-i beytin rivâyetlerine mutlak teslimiyet olduğunu, bu sebeple Caferîlerin, kendi görüşlerine ters düşen bütün görüş ve rivâyetleri geçersiz saydıklarını söylemektedir. Tabersînin, Caferîlerin klasik tutumundan farkı, kendi mezhebini savunma sadedinde rivâyetlerin yanında aklî yöntemlere de başvurması ve Sünnî âlimleri tartışmaya konu etmiş olmasıdır. Söz gelimi, âyetin “.... أو لامستم أنساء...” kısminı tefsir ederken Hz. Alî, İbn Abbâs, Mucâhid, Suddî ve Katâde'den bunun cimâ olduğuna dair aktarımda bulunmuş ve Ebû Hanîfe'nin de bu görüşte olduğunu belirtmiştir. Diğer taraftan Ömer b. el-Hattâb, İbn Mes'ûd, Şa'bî ve 'Atâ'dan ise âyetin söz konusu kısmının mutlak dokunma olduğuna dair nakillere de yer vermiş ve İmâm Şâfiînnin tercihinin de mutlak dokunma olduğunu söylemiştir. ${ }^{49}$

Tabersî, Caferîlerin görüşünü şu iki gerekçeyle temellendirmektedir: ${ }^{50}$

1) Lemese veya lâmesenin her ikisi de cimâ anlamındadır. Birinin sülâsî mücerred siygası, diğerinin mufâ‘ale/muşâreke siygası ile kullanılması sonucu etkilemez. Zira dokunma iki kişi arasında gerçekleşir. Burada, dokunma ile kastedilen anlam mecâzîdir.

2) Suyun yokluğu durumunda, Nisâ sûresi 43. âyetin, “...eğer cünüp iseniz temizlenin...” emri ile cünüplüğün teyemmüm ile giderilmesi gerektiği anlatılmıştır. Şu halde, suyun bulunduğu normal durumu ele alan Mâide sûresi 6. âyetteki “...kadınlara dokunduğunuzda...” kısmının cimâ olarak anlaşılması gerekir. Zira normal durumlarda cünübün nasıl temizlenmesi gerektiği hususu Şâri' tarafından açılanması zorunlu bir durumdur. Dokunma cimâ olarak anlaşılmayacak olursa, suyun bulunduğu durumlarda cünüplükten y1kanılması gerektiği hususu çözümsüz/hükümsüz kalmış olacaktır.

\section{2. Şî̂-Zeydî Mezhebi}

\subsubsection{Görüşleri}

Zeydîler, “.... أو لامستم النساء i...” ifadesinden cinsel münasebet anlamı çıkardıkları için, karşı cinslerin birbirine dokunmalarının hiçbir şekilde abdesti bozmayacağını kabul

48 Bk. Hasenî, Şerḥu't-Tecrîd, 1/180; Sâlimî, Me âricu'l-A'mâl 'alâ Medârici'l-Kemâl, 1/257.

49 Tabersî, Mecma'u'l-Beyân, 3/79. Burada Tabersî̀nin, klasik Caferî anlayıştan farklı olarak, Sünnî görüşlerden de istifade ettiğine temas ettik. Nitekim görüşlerini temellendirirken kullanmış olduğu delillerin aynısının İbn Kesir tarafindan da zikredilmiş olması bunun bir göstergesidir. Krş. Imâduddîn Ebu'l-Fedâ İsmâîl İbn Kesîr, Tefsîru'l-Kur'âni'l-'Azîm (Kahire: Müessesetü'l-Kurtubâ/Mektebetu Evlâdi'ş-Şeyh li'tTürâsi, 1421/2000), 5/463-465.

50 Tabersî, Mecma'u'l-Beyân, 3/79. 
ederler. ${ }^{51}$ Zeydîlerin en önemli kaynakları arasında yer alan Şerhu't'-Tecrîdfî̌ Fukhi'z-Zeydîyye adlı eserde, müellif, ehl-i beyt fakihlerinin yukarıda zikredilen görüş üzerinde icmâ ettiklerini ifade etmiştir. ${ }^{52}$

Zeydîler, "kendisiyle evlenilmesi yasak olmayan (nâmahrem) kadına şehvetle dokunma durumunda abdest bozulur" diyen İmâm Mâlik ile Hanbelîlerin ve "mutlak anlamda nâmahrem kadına dokunmak abdesti bozar" diyen Şâfiîlerin kayda değer hiçbir sahih delillerinin olmadığını savunurlar. ${ }^{53}$ Hatta bazı Zeydîâlimler, Şâfiî mezhebinin en zayıf ictihâdının bu olduğunu belirtirler..$^{54}$

Ne var ki, bu konuda birbirine zıt iki görüş arasında mutedil yaklaşım sergileyen Zeydî âlimler de vardır. Söz gelimi, Şevkânî, Mecdüddîn İbn Teymiyye'nin (öl. 652/1254) Münteka'l-Ahbâr başlıklı eserine yazmış olduğu Neylü'l-Evțâr adlı (şerh) kitabında, konu ile ilgili birbirine zıt rivâyetleri/hadîsleri şerh ettikten sonra, Mecdüddîn İbn Teymiyye'nin, mezheplerin görüşlerine yer verme sadedinde zikrettiği "kadına şehvetle dokunulduğunda abdest bozulur görüşünün mutedil (evsat) bir görüş olduğu” şeklindeki fikrini eleştiriye tâbi tutmadan, yorumsuz bir şekilde aktarır. ${ }^{55}$

\subsubsection{Delilleri}

Zeydîler, mülâmese konusunda Caferîlerle aynı görüşü paylaşmaktadırlar. Fakat burada özellikle temas edilmesi gereken bir husus vardır ki, o da, Zeydîlerin, bu meseleyi delillendirmeye çalışırken gerek başvurdukları kaynaklar ve gerekse diğer mezhep ya da âlimlerin görüşlerinin isabet edip etmemesi konusunda Caferîlerden oldukça farklı bir yöntem izlemiş olmalarıdır. Şöyle ki, Zeydîler, Caferîlerden farklı olarak mülâmese konusunun naklî delillerin yanı sıra lugavî ve aklî delillerle de anlaşılabileceğini savunmuşlardır. Bu sebeple Zeydîler, görüşlerini temellendirmeye çalışırken Caferîlerden farklı olarak ehl-i beyt imâmlarından gelen rivâyetlerin yanında Sünnî âlimlerden gelen bazı rivâyetlere, birçok lugavî ve aklî delillere de başvurmuşlardır. Mesela Hasenî, Haymî es-San'ânî ve Şevkânî gibi bazı Zeydî âlimler, özellikle Hanefîlerin başvurdukları delilleri kullanmışlardır. Zeydîler, aklî ve lugavî delillendirmeye o kadar yer vermişlerdir ki, kendilerinden farklı görüşe sahip olan bazı âlim ve mezheplerin delillerinin genelde lugavî ve aklî istidlallerle zayıf olduklarını ispat etmeye çalışmışlardır. Görüldüğü üzere Zeydîler aklî deliller

51 Hasenî, Şerhu't-Tecrîd, 1/177; Emîr es-San ‘̂nî, Sübülü's-Selâm, 1/193; Şevkânî, Neylü’l-Evțâr, 1/554-559.

52 Hasenî, Şerhu't-Tecrîd, 1/177. Benzer ifadeler için ayrıca bk. Emîr es-Sanânî, Sübülü's-Selâm, 1/193; Şevkânî, Neylü'l-Evțâr, 1/554-559.

53 Mâlikîlerin görüsleri hakkında daha fazla bilgi edinmek için bk. Ebû Saîd Abdüsselâm b. Saîd b. Habîb etTenûhî (Sahnûn), Müdevvenetü'l-Kübrâ (Beyrut: Dâru Sadr, ts.), 1/13; Ebû Abdillâh Muhammed b. Muhammed el-Mağribî, Mevâhibu'l-Halîl (Beyrut: Dâru'l-Kütübi'l-İlmiyye, ts.), 1/429-430; Sâvî Abdurrahmân el-Garyanî, Mudevvenetu'l-Fıkhi'-Mâlikîve Edilletuhu (Beyrut: Müessesetü'r-Reyyân, 1423/2002), 1/167. Şâfiîlerin görüşü için bk. Şihâbuddîn Ahmed b. Muhammed b. Alî Ibn Hacer el-Heytemî, Tuhfetu'l-Muhtâcfi Şerhi'l-Minhâc

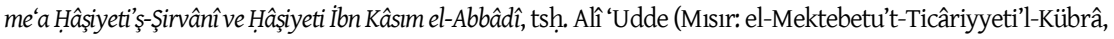
1357/1983), 1/137; Nevevî, Ravżatu't-Ṭâlibîn, 1/34; Büceyremî, el-Büceyremî 'ale'l-Hatîb, 1/311.

53 Daha fazla bilgi için bk. Ebû Muhammed Muvaffakuddîn Abdullâh b. Ahmed İbn Kudâme, el-Mugnnî Şerhu Muhtasari'l-Hurâkî (Riyâd: Dâru'l-Kütübi'l-ìlmiyye), 1/258-259.

54 Sâlih b. Mehdî el-Makbilî, el-Menâr fi'l-Muhtâr min Cevâhiri'l-Bahri'z-Zahhâr (Beyrut: Müessesetü'r-Risâle, 1408/1988), 1/82.

55 Şevkânî, Neylü'l-Evțâr, 1/559. 
getirmede, Sünnî mezheplerden de yararlandıkları için konuyu delillendirme noktasında oldukça geniş bir perspektif ortaya koymuşlardır. ${ }^{56}$

Zeydîlerin, karşı cinse dokunmanın abdesti bozmayacağını savunurken dayandıkları en önemli naklî ve aklî delillerden bazıları şunlardır:

1) Ebû Hâlid şöyle diyor: "Zeyd b. Alîye: '(Kadını) Öpmenin abdesti bozup bozmadığını sordum', o da: 'Abdesti sadece hades (necâset) bozar; bu ise hades değildir', dedi”. ${ }^{57}$

2) Hz. Âişe şöyle dedi: “(Hz. Peygamber) Hantmlarından birini öptü ve abdest almadı". ${ }^{8}$

3) Hz. Âişe: "Efendimiz beni öptü ve abdest yenilemeden namaz kıldı" dedi. ${ }^{59}$

4) Hz. Âişe şöyle dedi: "Efendimiz hantmlarından birini öper ve abdest almazdi" ${ }^{60}$

5) Ümmü Seleme'nin şöyle dediği aktarılmaktadır: "Hazreti Peygamber oruçlu olduğu halde beni öptü, orucunu bozmadı ve abdest yenilemedi". ${ }^{61}$

6) Hz. Âişe: “Gecenin birinde Efendimizi elimle yokladım, secde ederken elim ayağının tabanina değdi. O secdede şöyle şöyle dua ediyordu" dedi. ${ }^{62}$

Bu rivâyetten, Efendimizin namazına devam ettiği anlaşılmaktadır. Bu sebeple eğer kadınlara dokunmak abdesti bozsayd 1 Efendimiz namaza devam etmezdi. ${ }^{63}$

7) Hz. Âişe şöyle dedi: "Hz. Peygamber, mülâmesenin cinsel beraberlik olduğunu söyledi”. ${ }^{64}$

8) Hz. Alî: ““،.... أو لامستم النساء "...” ifadesinden kast edilen cinsel birlikteliktir” dedi. ${ }^{65}$

9) Hz. Âişe: "Hz. Peygamber namaz kılardı ben de cenazenin uzandığı gibi onun önünde uzanırdım. Vitir namazına kalkacağı zaman beni ayağı ile dürterdi” dedi. ${ }^{66}$

10) Nisâ 43. ile Mâide 6. âyetlerde yer alan “... أو لامستم النساء i...” ifadesi cimâ olarak anlaşılmayacak olursa bu âyetlerin ele aldıkları hususlar noktasında bir tutarsızlık, düzensizlik ve hükümde eksiklik ortaya çıacaktır. Şöyle ki; Mâide 6. âyette abdest alınması gereken durumlar açılandıktan sonra gusül alınması gereken durum; “...eğer cünüp iseniz temizlenin...”, emri ile ifade edilmiştir. Nisâ 43. âyette ise, “...ya da kadınlara dokunduğunuzda..." ifadesi ile abdestin bozulduğu hallerde, suyun yokluğu durumunda teyemmüm alınması gerektiği emredilmiş ve cünüplüğün teyemmümle kaldırılmasının meşru olduğu belirtilmiştir. Eğer bu âyetteki, “...ya da kadınlara dokunduğunuzda...” ifadesi cimâ olarak anlaşılmayacak olursa suyun yokluğu durumunda cünüplüğün teyemmümle kaldırılabileceği hükmü ifade edilmemiş ve eksik bırakılmış olacaktı. ${ }^{67}$

56 Ḥasenî, Şerhu’t-Tecrîd, 1/177-181; Haymî es-San'ânî, er-Ravżu'n-Nażîr, 1/206-207; Şevkânî, Fethu'l-Kadîr, 1/752; a. mlf., Neylü'l-Evtâr, 1/557.

57 Ebu'l-Huseyn Zeyd b. Alî, Müsnedü'l-Immâm Zeyd (Lübnan: Dâru'l-Kütübi'l-illmiyye, ts.), 58; Haymî esSan'ânî, er-Ravżu'n-Nażîr, 1/204.

58 Ḥasenî, Şerhu't-Tecrîd, 1/177.

59 Ḩasenî, Şerhư't-Tecrîd, 1/177. Bu hadîs aynı zamanda Sünnî kaynaklarda da yer almaktadır. Bk. Ebû Dâvûd, "Tahâret”, 67; Tirmizî, "Tahâret”, 63; Nesâi, "Tahâret”, 121; ỉbn Mâce, "Tahâret”, 69; ỉbn Hanbel, Müsned, 6/210.

60 Ḥasenî, Şerḥu't-Tecrîd, 1/177. Ayrıca Sünnî kaynaklar için bk. Nesâ̂, "Tahâret”, 118.

${ }^{61}$ Ḩasenî, Şerhu't-Tecrîd, 1/178; Şevkânî, Fethu'l-Kadîr, 1/752. Ayrıca Sünnî kaynaklar için bk. Tirmizî, "Tahâret", 136.

62 Tirmizî, "De'avât", 77; Nesâî, "Tahâret", 120; İbn Mâce, "Dua”, 3.

${ }^{63}$ Ḥasenî, Şerhu't-Tecrîd, 1/188; Şevkânî, Fethu'l-Kadîr, 1/752; a. mlf., Neylül'-Evtâr, 1/557.

64 Hasenî, Serhu't-Tecrîd, 1/179.

65 Hasenî, Șerhu't-Tecrîd, 1/179.

66 Nesâ̂, “Tahâret”, 120; İbn Hanbel, Müsned, 5/44; Şevkânî, Neylü'l-Evtâr, 1/557.

67 Emîr es-San'ânî, Sübülü’s-Selâm, 1/193; Haymî es-San'ânî, er-Ravżu'n-Nażîr, 1/206. 


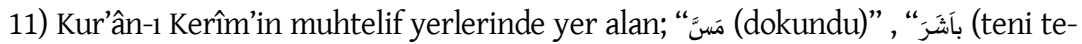
nine değdi)” ve "مَا سنَ (birbirine dokundular)” gibi kelimelerin/terimlerin mecâzen cimâ anlamında kullanıldıkları gayet açıktır. O halde ilgili âyetlerde yer alan dokunma (lemese/lâmese) da cimâ anlamındadır. ${ }^{68}$

\subsection{3. İtirazlara/Karşıt Görüşlere Verdikleri Cevaplar}

Zeydîler, yukarıda bir kısmını vermiş olduğumuz ve Efendimizin, eşlerine dokunduğu halde abdest yenilemeden namaz kıldığını bildiren rivâyetler için, "bu dokunmaların arada perde vb. bir şeyin bulunduğu halde olma ihtimali vardır”, ${ }^{69}$ diyenlere şöyle cevap vermişlerdir: "Bu düşünce geçersizdir. Zira bu, hakîkî manayı terk ederek mecâza hamletmek olacaktır. Oysa burada, manayı mecâza hamletmek için geçerli bir karine ve sebep yoktur".70

Mülâmesenin mutlak dokunma anlamında olduğunu ifade eden bazı sahabe kavillerini $^{71}$ delil gösterenlere, "Hz. Peygamber ve Hz. Alî’den dokunmanın cimâ olduğunu ifade eden sözler rivâyet edildiği için bunların delil kabul edilmeleri mümkün değildir”, şeklinde cevap verirler. ${ }^{72}$

“Hz. Âişe'den nakledilen ve Hz. Peygamber'in eşlerine dokunduğunu, onları öptügünü ve abdest almadan namaz kıldığını bildiren rivâyetler Ebû Dâvûd, Nesâi ve Beyhakî gibi önemli muhaddisler tarafından zayıf sayıldıkları için bu konuda delil olamazlar" diyenlere şöyle cevap verirler: "Evet rivâyetlerin bir kısmı zayıftır. Ancak bu rivâyetin on farklı tarikinin bulunması rivâyetlerin birbirini güçlendirdiğini gösterir". ${ }^{33}$

Zeydîler, "mülâmese karşı cinse mutlak dokunmadır", diyenlere de şöyle cevap verirler: "Evet, lâmese veya lemesenin hakîkî manası mutlak dokunmadır. Fakat örfî kullanım, lugavî kullanımın önüne geçerek onun, hakîkî anlamı dışında mecâzen cimâ anlamında kullanılmasını sağlamıștır. Söz gelimi, "dâbbe" ve ilgili iki âyette de yer alan "ğâit" kelimelerinde de durum aynıdır. Şöyle ki; normalde dâbbe kelimesinin lugavî kullanımda bütün canlılar için kullanılırken örf bunu özel bir hayvan olan merkep anlamına tahsis etmiştir. Ğâit kelimesi ise, lügatta çukur ve alçak yer anlamında kullanılır. Ancak def-i hacet genelde bu tür yerlerde yapıldığı için def-i hacet anlamına tahsis edilmiş ve ğait denildiğinde def-i hacetten başka bir şey anlaşılmaz olmuştur. Dolayısıyla bir kelimenin örf vb. sebeplerden dolayı hakîkî mana dışında kullanıldığı tartışılmazdır. Mülâmese konusunda da durum aynen böyledir" ${ }^{74}$

68 Haymî es-San'ânî, er-Ravżu'n-Nażîr, 1/203.

69 Bu delili, Şâfî̂ âlimleri, mezheplerinin görüşlerini savunurken kullanırlar. Bk. Büceyremî, el-Büceyremî 'ale'l-Hatîb, 1/311.

70 Hasenî, Şerhu't-Tecrîd, 1/178.

71 İbn Ömer ve İbn Mes'ûd'dan gelen rivâyetlere göre lems; mutlak anlamda dokunmadır. Bk. Ebû Abdillâh Mâlik b. Enes, el-Muvatța, tḥk. Beşşâr 'Avl Ma'rûf (Beyrut: Dâru'l-Ğarbi'l-İslâmî, 2. Basım, 1417/1997), “Tahâret”, 16; Şemsuddîn Muhammed b. Ebi'l-Abbâs Ahmed b. Hamza b. Şihâbiddîn er-Remlî. Nihâyetu'lMuhtâc ilâ Şerhi'l-Minhâc (eş-Şebrâmellisî ve el-Mağribî er-Reşîdînin haşiyeleriyle), (Beyrut: Dâru'l-Fikr, 1404/1984), 1/16; Şevkânî, Neylü'l-Evțâr, 1/195.

72 Haymî es-San'ânî, er-Ravżu'n-Nażîr, 1/203.

73 Şevkânî, Neylü'l-Evțâr, 1/557; Emîr es-San'ânî, Sübülü's-Selâm, 1/193.

74 Makbilî, el-Menâr fi'l-Muhtâr, 2/96; Hasenî, Şerhu't-Tecrîd, 1/179, 180; Şevkânî, Neylü'l-Evtâr, 1/555. 
Şevkânî de, “.... أو لامستم النساء "..." ifadesini tefsir ederken, özellikle "lemese” kıraâtini esas alarak; "mülâmesenin mutlak dokunma anlamı gibi cimâ anlamını da ihtiva ediyor olması muhtemeldir. Bu sebeple her iki manaya ihtimalli olan bu ifadeleri mutlak dokunma anlamina hamletmekle, sıklıkla karşılaşılan (umûmî belvâ kabilinden olan) bu meselede insanlara büyük bir meşakkat yüklenilmiş olacağını" söyler. Bu sebeple, konu ile ilgili diğer delilleri de göz önünde bulundurularak, "lemese” kelimesinin insanlar için daha kolaylaştırıcı olan muhtemel manaya hamledilmesi gerektiğini savunur. ${ }^{75}$

Zeydîler, “Adamın biri Efendimizin yanına gelerek: 'Ey Allah'in Resulü ben kadının birine cimâ dışında bir erkeğin bir kadına yapabileceği her şeyi yaptım', deyince Efendimiz de adama: 'Abdest al ve namaz kl' buyurmuştur" ${ }^{\text {"76 }}$ şeklindeki rivâyete dayanarak, kadına dokunmanın abdesti bozacağı görüşünü savunanlara şu şekilde cevap verirler: 1) Adamın kadına dokunmadan önce abdestli olduğuna ve dokunma neticesinde abdestinin bozulduğu için abdest alması istendiğine dair herhangi bir ipucu yoktur. 2) Adamın, kendisinden dokunmadan kaynaklı necâsetin (mezinin) çıkmış olabileceği gerekçesiyle, abdestinin bozulmuş olma ihtimali vardır. ${ }^{77} 3$ ) Kişinin helali olmayan bir kadına bu şekilde şehvetle dokunması büyük günahtır. Bize göre, büyük günahlar abdesti bozar. ${ }^{78} \mathrm{Bu}$ rivâyet de munkatı' bir rivâyettir. Munkatı' rivâyet ise böylesi bir meseleye delil teşkil edemez. $^{79}$

Zeydîler, "lemese" kıraâtini esas alarak bunun "lâmese" siygasından farklı olduğundan yani muşâreke (ortaklık) ifade etmediğinden dolayı "mutlak dokunma" anlamında olması gerektiğini iddia edenlere şöyle cevap verirler: "Evet, lemesenin manası mutlak dokunmadır. Ancak onu lâmese anlamına hamlediyoruz. Zira bu iki farklı k1raâti, farklı anlamlarda kabul eden hiçbir âlim olmamıştır. Başka bir deyişle, bütün âlimler esas aldıkları kıraâtin dışında kalan diğer kıraâti, mana açısından esas aldıkları kıraâte hamletmişlerdir. Biz de, lâmesenin manasını cimâ olarak kabul ettiğimiz için lemeseyi de ona hamlettik". ${ }^{80}$

\subsection{Haricî-İbâzî Mezhebi}

\subsubsection{Görüşleri}

İbâzîler, karşı cinse mutlak dokunmanın abdesti bozmayacağını savunurlar. Fakat onlara göre günah addedilen her türlü söz, fiil ve tutum abdesti bozar. ${ }^{81}$ Bu sebeple bir kişinin, bir kadının vücudunun görülmesi caiz olmayan her hangi bir yerine kasıtlı ya da kasıtsız olarak bakması ve ona dokunması yahut da onun el, yüz gibi görülmesi caiz olan bir yerine şehvetle bakması durumunda abdestinin bozulacağını savunurlar. ${ }^{82}$

\footnotetext{
75 Şevkânî, Fethu'l'-Kadîr, 1/301, 302.

76 Ḥasenî, Şerḥu't-Tecrîd, 1/180, 181.

77 Haymî es-San'ânî, er-Ravżu'n-Nażîr, 1/207.

78 Şevkânî, Neylül-Evțâr, 1/554-555.

79 Şevkânî, Fethu'l-Kadîr, 1/752.

80 Hasenî, Şerhu't-Tecrîd, 1/180.

81 Muhammed İbrâhîm el-Kindî, Beyânu'ş-Şer' (Mesḳaț/Ummân: Vezâretü't-Türâsi'l-Kavmî ve'ș-Sekâfe, 1405/1984), 8/187; 'Âmir b. Alî eş-Şemmâhî, Kitâbu'l-î́âh (Mesḳaț/Ummân: Vezâretü't-Türâsi'l-Kavmî ve's-Sekâfe, 4. Basım, 1420/1999), 1/124-129, 136, 137.

82 Sâlimî, Me âricu'l-A'mâl, 1/229, 230; Kindî, Beyânu'ş-Şer' , 8/158-160.
} 
İbâzîlere göre, mahrem (evlenilmesi ebedî haram) olan kadının, mahremi olan erkeğe karşı avret mahalli diz kapağı ile göbeği arasıdır. Bu sebeple mahrem olan erkeğin, mahreminin avret olmayan bölgelerine şehvetsiz dokunması abdestini bozmaz, ancak bu yerlere șehvetle dokunması durumunda abdesti bozulur. ${ }^{83}$

Diğer taraftan bazı İbâzî âlimlere göre, mahrem olmayan (evlenilmesi caiz olan) kadınların el ve yüzlerine bakmak caiz olduğu için bu bölgelere dokunmak da caizdir. Bu görüşe göre, zikredilen bölgelere şehvetsiz olarak bakılmasında abdest bozulmayacağı gibi şehvetsiz olarak dokunulmasında da abdest bozulmaz. Bu görüş, mezhebin önemli bazı eserlerinde nakledilmesine rağmen mezhepte muteber görüş değildir. Mezhep içerisinde sahih kabul edilen görüş ise şudur: Dokunmak bakmaktan farklıdır. Zira dokunmak şehveti celp etme hususunda daha etkilidir. Bu sebeple bakılması caiz olan yerlere dokunmak abdesti bozar. ${ }^{84}$ ibazîlerin mülâmese hakkındaki muteber görüşü bu şekilde olmakla birlikte, şehvetin varlığını göz önünde bulundurmadan yabancı (nâmahrem) kadına kasıtlı veya kasıtsız olarak dokunmanın abdesti bozacağı görüşü de mevcuttur. ${ }^{85}$

Yine onlara göre, bakılması ve dokunulması durumunda günah söz konusu olmadığı için eşlere veya şehvet duyulmayacak kadar yaşlı (âyise) olan kadınlara bakmak ve dokunmak da abdesti bozmaz. ${ }^{86}$ Ayrıca saça, tırnağa ve dişe dokunmak da abdesti bozmaz. ${ }^{87}$

İbâzîler, yukarıda, dokunulması abdesti bozar diye ifade ettikleri yerlerde sadece dokunan kişinin abdestinin bozulacağını, dokunulan kişinin ise abdestinin bozulmayacağını ayrıca belirtirler. ${ }^{88}$

İbâzîlerin, ilk dönem fikıh kitaplarında, ilgili âyetlerin söz konusu ifadesinin mutlak dokunma veya cimâ anlamında olduğu hususu üzerinde pek durmadıkları, daha çok günâh sayılan bakışların ve dokunmaların abdesti bozduğu konusuna odaklandıkları görülmektedir. Fakat zamanımıza yakın tarihlerde yazılan İbâzî fikıh kitaplarında Sünnî kaynaklardan çok yararlanmışlar ve Hanefî fikıhçılarına benzer bir metot izleyerek söz konusu ifadelerin cimâ anlamında olduğu üzerinde durmuşlardır. ${ }^{89}$

Kısaca İbâzîlere göre, karşı̣ cinse mutlak dokunma abdesti bozmaz. Ancak açl-ması/bakılması haram olan avret bölgelerine bakılması veya el, yüzve ayakaltları gibi açılması/bakılması haram olmayan bölgelere şehvetle dokunulması durumunda günah işlenmiş olacă̆ı için abdestin bozulacağını savunurlar.

83 Sâlimî, Mêâricu'l-A'mâl, 1/229, 230; Kindî, Beyânu'ş-Ser', 8/158-160.

84 Şemmâhî, Kitâbu'l-İzâh , 1/137, 139.

85 Şemmâhî, Kitâbu'l-İzâh̆, 1/137; Tafeyyîş, Şerhu Kitâbi'n-Nîl, 1/136.

86 Muhammed b. Yûsuf et-Tafeyyîs, Şerhu Kitâbi'n-Nîl ve Şifâi'l-'Alîl (Cidde: Mektebetu'l-İrşâd-Beyrut: Mektebetu'l-Feth, ts.), 1/136; Şemmâhî, Kitâbu'l-1̌̇âh̆, 1/137; Sâlimî, Me'âricu'l-Â'mâl, 1/229, 230.

87 Tafeyyîs, Şerhu Kitâbi'n-Nîl, 1/136.

88 Șemmâhî, Kitâbu'l-1̌żâh, 1/137.

89 Söz gelimi, yaklaşık bir asır önce kaleme alınan, Me âricu'l-A'mâl adlı eserde bunu daha net bir şekilde görmekteyiz. İlk asırlarda yazılan İbâzî fikıh kitaplarında ilgili âyetlerde yer alan mülâmese üzerinde pek durulmaz, sadece günâh olan hususların abdeste etkisi bağlamında, haram bakış ve dokunuşların abdesti bozduğu söylenir. Oysa yukarıda zikredilen eserde mülâmese konusu geniş bir şekilde ele alınmıştır. Daha fazla bilgi için bk. Sâlimî, Méâricu'l-A'mâl, 1/253-260. 


\subsubsection{Delilleri}

1) Hz. Âișe'nin, “Gecenin birinde Efendimizi elimle yokladım, secde ederken elim ayağının tabanına değdi. O secdede şöyle şöyle dua ediyordu" șeklindeki rivâyetinde, dokunma sonucunda Hz. Peygamber'in namazına devam ettiği anlaşılmaktadır. Bu sebeple eğer kadınlara dokunmak abdesti bozsaydı Efendimiz namaza devam etmezdi.

2) Yine Hz. Âişe'nin, “Efendimiz beni öptü ve abdest yenilemeden namaz kıld”" şeklindeki rivâyeti.

3) Hz. Peygamber'den rivâyet edilen, “(Helaliniz olmayan) Kadınların güzellikleri size haram kulınd" "92 mealindeki hadîs.

Bu hadîs, esasında mezhepteki, günaha sebep olan haram bakışlar ve dokunuşlar abdesti bozar görüşünün delilidir.

4) Araplarla mevâlî arasında mülâmesenin ne olduğu hususunda çıkan tartışma üzerine İbn Abbâs'ın dediği, 'Kur'ân'da bahsedilen mülâmese cimâdır'93 şeklindeki söz/görüş.

Son dönemlerdeki İbâzî kaynaklarda bu delil, mülâmesenin cimâ anlamında olduğu görüşünü desteklemek üzere zikredilmektedir.

5) Lâmese kelimesi mufấale kipinde olması yani müşareket bildirmesi sebebiyle İbâzîler tarafından "cimâ" şeklinde anlaşılmış ve bu bağlamda "lemese" kelimesi de "lâmese"ye hamledilmiştir. ${ }^{94}$

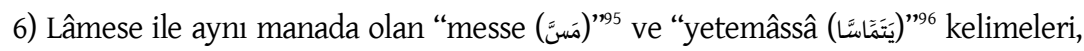
Kur'ân-1 Kerîm'in muhtelif yerlerinde cimâ anlamında kullanılmıştır. Dolayısıyla lâmese kelimesi de cimâ anlamında kullanılmalıdır. ${ }^{97}$

7) Hades, biri küçük diğeri büyük olmak üzere iki çeşittir. Âyet-i kerîmelerde küçük hades, def-i hacet ${ }^{98}$ olarak ifade edilmiş; büyük hades ise, ilgili âyetlerde "... ألنستم النساء..." (ev lâmestumu'n-nisâe)..." kısmında olduğu gibi mülâmese ile ifade edilmiştir. ${ }^{99}$

90 Şemmâhî, Kitâbu'l-İzâh, 1/139, 140. Aynı hadîsin Sünnî kaynaklardaki rivâyeti için bk. Müslim, "Salât", 22; Nesâî, "Tahâret", 120; İbn Mâce, "Dua”, 3.

91 Sâlimî, Meâricu'l-A'mâl, 1/256; Dârekuțnî, Sünen, 1/245.

92 Şemmâhî, Kitâbu'l-1̌zâh, 1/137.

93 Sâlimî, Me'âricu'l-A'mâl, 1/256.

94 Sâlimî, Me'âricu'l-A 'mâl, 1/257.

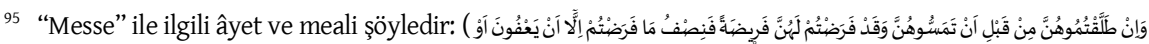
(يَّةer onlara mehir tespit eder de kendilerine el sürmeden (beraber olmadan) boşarsanız, tespit ettiğiniz mehrin yarısı onlarındır. Ancak kadının, ya da nikâh bağı elinde bulunanin (kocanın, paylarından) vazgeçmesi başka. Bununla birlikte (ey erkekler), sizin vazgeçmeniz takvaya (Allah'a karşı gelmekten sakınmaya) daha yakındır. Aranızda iyilikyapmayı da unutmayın. Şüphesiz Allah, yaptiklarınızı hakkıyla görendir". Bk. el-Bakara 2/237.

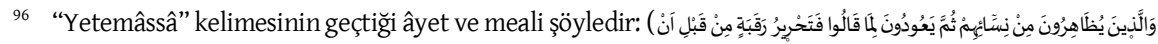

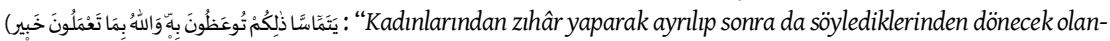
lar, eşleriyle birbirlerine dokunmadan (beraber olmadan) önce, bir köle azat etmelidirler. İște bu hüküm ile size öğüt veriliyor. Allah, yaptıklarınızdan hakkiyla haberdardı"”. Bk. el-Mücâdele 58/3.

97 Sâlimî, Me'âricu'l-A'mâl, 1/257.

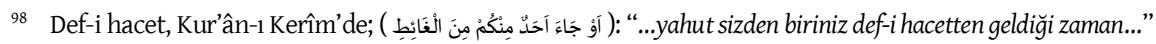
şeklinde zikredilir. Bk. en-Nisa 4/43; el-Mâide 5/6.

99 Sâlimî, Me âricu'l-A'mâl, 1/257. 


\subsection{3. İtirazlara/Karşıt Görüşlere Verdikleri Cevaplar}

Lâmesenin hakîkî manasının dokunma olduğunu söyleyenlere: "Evet, lâmesenin hakîkî manası mutlak dokunma olmakla beraber, "ğâit" ve "nikâh" kelimelerinde olduğu gibi, âyetlerde mecâzen cimâ anlamında kullanılmıştır" ifadeleriyle cevap verirler. ${ }^{100}$ Ayrıca Hz. Peygamber'in, eşlerini öptüğü ve abdest almadan namaz kıldığı rivâyetleri de mülâmesenin cimâ anlamında anlaşılması gerektiğine delildir. ${ }^{101}$

Mülâmesenin yer aldığı âyetlerden biri olan en-Nisâ 4/43’te, “...cünüp isenizyıkanmadan namaza yaklaşmayın...”, ifadesi/emri açı bir şekilde yer almaktadır. Buna göre mülâmeseyi de cimâ şeklinde anlamak âyette aynı konunun iki defa tekrar edilmiş olmasını gerektirir, diyenlere ise: "Hayır, mülâmeseyi cimâ olarak anlamak mutlak anlamda tekrarı gerektirmez. Zira “...cünüp iseniz yıkanmadan namaza yaklaşmayın...” ifadesi geneldir; ihtilam sebebiyle veya sebepsiz yere gerçekleşen inzal gibi cünüplüğü de kapsar. Mülâmese ise, sadece cimâdan kaynaklanan cünüplüktür. Yani birinci ifade âmm lafız iken ikinci ifade hâs lafızdır", şeklinde cevap verirler. ${ }^{102}$

\section{Değerlendirme ve Sonuç}

Fıkıhçlar, abdest ve teyemmümün ele alındığı, Nisâ Sûresi 43. ve Mâide Sûresi 6. âyetlerde yer alan “.... (أو لامستم النساء (ev lâmestumu'n-nisâe/ya da kadınlara dokunduğunuzda)..." ifadesinin manası hakkında ihtilaf etmişlerdir. Fukahânın bir kısmı âyetlerdeki ifadenin mutlak dokunma anlamında olduğu ve bu sebeple evlenilmesi caiz olan (nâmahrem) kadına dokunmanın abdesti bozacağı; buna karşılık bazıları ise, bu ifadenin cinsel birliktelik anlamında olduğu ve dolayısıyla salt dokunmanın abdesti bozmayacağı ictihâdında bulunmuşlardır.

Söz konusu ihtilafın genel itibariyle şu iki sebebe dayandığını söylemek mümkündür: Birincisi, ilgili kelimelerin hakîkî/sözlük manalarının "mutlak dokunma", "el ile dokunma" ve "el ile yoklama" anlamında olduğu halde mecâzen "cimâ" anlamında da kullanılıyor olmalarıdır. İkincisi ise, âyetlerdeki ifadelerin "mutlak dokunma" ve "cimâ" anlaminda olduğunu belirten rivâyetlerin bulunması ve bunlardan herhangi birinin sıhhatı üzerinde uzlaşılamamış olunmasıdır.

Çalışmamızda "lems" ve "mülâmese" ifadelerinin Şî̂-Caferî, Şî̂-Zeydî ve Haricî-İbâzî mezhepleri tarafından nasıl anlaşıldığı; konuyla ilgili görüşleri, delilleri ve karşıt görüşteki fakih veya mezheplere vermiş oldukları cevaplar serdedilmeye çalışılmıştır.

Öncelikle ifade etmek gerekir ki; İbâzî mezhebinin, "karşı cinse dokunmanın günah olduğu bazı durumlarda, abdestin bozulacağı" görüşünü hariç tutacak olursak, Sünnî olmayan bu üç mezhebin, karşı cinse mutlak anlamda dokunmanın, abdesti bozmayacağ hususunda ittifak ettiklerini söylemek mümkündür. Ne var ki, bu üç mezhep söz konusu meseleyi ele almaları ve özellikle de görüşlerini temellendirmeleri noktasında birbirlerinden oldukça farklı yol ve yöntemler sergilemişlerdir.

Yukarıda verilen ön bilgiden sonra, çalışmada elde edilen bulguları mezhepler bağlamında şöylece ortaya koymak mümkündür:

\footnotetext{
100 Şemmâhî, Kitâbu'l-1̂̀zâh, 1/139.

${ }^{101}$ Sâlimî, Me'âricu'l-A'mâl, 1/258.

102 Sâlimî, Me âricu'l-A'mâl, 1/258.
} 
Caferîler, söz konusu âyet-i kerîmelerde yer alan “.... أو لامستم النساء i...” ifadesinin cimâ anlamında olduğunu, bu sebeple karşı cinse mutlak anlamda dokunmanın abdesti bozmayacağını savunurlar. Çünkü onlara göre, bu konu hakkında, ehl-i beyt imâmlarından söz konusu ifadelerin cimâ anlamında olduklarını ifade eden rivâyetlerin geldiği kabul edilir.

Caferîlerin, ehl-i beyt imâmlarını masum kabul etmeleri, dahası onların vahiy aldıklarına, Kur'ân-1 Kerîm'in ehl-i beyte nazil olduğuna ve bu sebeple de Kur'ân-1 Kerîm'i hakkıyla sadece onların anlayabileceğine inanmaları konusunda icmâ ettikleri görülmüştür. Dolayısıyla bu konuda, Caferîlerin görüş ayrılığı içerisinde olmadıkları rahatlıkla söylenilebilir.

Caferîler, kendilerine özgü hadîs anlayışına istinaden muhafazakâr tavır sergilemeleri sebebiyle masum kabul ettikleri ehl-i beyt imâmlarından gelen rivâyetlere aykırı olan hiçbir rivâyeti ve ictihâdı kabul etmemişlerdir. O kadar ki onlar, görüşlerini savunma sadedinde, kendileriyle aynı görüşte olan bazı Sünnî mezheplerin konu hakkındaki birçok rivâyetini ve aklî istidlallerini kullanmamayı tercih etmişlerdir. Aynı şekilde söz konusu görüşlerini teyit etmek için, özellikle ilk dönemlerde, hiç bir lugavî ve aklî istidlale de başvurma ihtiyacı duymamışlardır.

Yine Caferîler, bahsi geçen görüşlerini sadece masum imâmların rivâyetleriyle savundukları için, kendilerinden farklı düşünen âlim veya mezheplere hiçbir şekilde cevap verme yoluna da gitmemişlerdir. Buna ilave olarak, muhtemelen ehl-i beytin rivâyetlerini sorgulamak anlamına geleceği için söz konusu ifadeleri kıyas veya ictihâd yöntemi ile anlamaya çalışma gayretlerini de şeytanî bir metot olarak nitelemişlerdir.

Caferîlerin bu korumacı tavırlarının, imâmlardan gelen rivâyetlerin hiçbir tenkit ve sorgulamaya tâbi tutulmadan tartışmasız olarak kabul edilmesi anlayışının temsilcisi olan Ahbârîlik geleneği/anlayışı ile hicri 6. asra kadar devam ettiğini söylemek mümkündür. Fakat zamanla Şîa içinde Ahbârîliğin yanında, Usûlîlik anlayışının da mezhepte kabul görmeye başlaması ve mutedil sayılabilecek bazı Şiî âlimlerin ortaya çıkmasıyla, serdettikleri görüşlerin, imâmların rivâyetleri yanında Sünnî kaynaklarda yer alan bazı rivâyetler ve lugavî ve aklî istidlal yöntemleriyle de savunulduğu görülmüştür. Şu halde, Caferîlerin âyeti anlama yöntemleri büyük oranda hadîs anlayışlarında sahip oldukları farklı usullerle alakalıdır. Onların hadîs anlayışları sadece imâmlardan gelen rivâyetleri hadîs olarak kabul etme üzerine bina edildiği için bu konuda da imâmlarının rivâyetleriyle yetinmişlerdir. Şu halde konuyla ilgili olarak imâmlardan gelen rivâyetler sadece cinsel ilişkinin abdesti bozacağını ifade ettiği için onların genel tavrı bu yönde olmuştur.

Zeydîler de, Caferîler gibi ilgili âyetlerde yer alan lâmesenin cimâ olduğunu, bu sebeple karşı cinse dokunmanın abdesti bozmayacağını ittifakla kabul etmişlerdir. Ancak Zeydîlerin konuya yaklaşımları Caferîlerden oldukça farklıdır. Şöyle ki, onlar, bu konuyu sadece ehl-i beyt imâmlarından gelen rivâyetler çerçevesinde temellendirmemişlerdir. Aksine onlar, görüşlerini ortaya koyarken Şîi kaynaklarında yer alan rivâyetlerden istifade ettikleri gibi, başta bazı Sünnî fakih ve mezheplerin başvurduğu birçok rivâyetten ve de aklî ve naklî delillerden son derece istifade etmişlerdir. Ayrıca Zeydîler, meselenin lugavî ve aklî istidlal yöntemleri ile ele alınmasının gerektiğine ve bunda herhangi bir problemin söz konusu olmadığına da vurgu yapmışlardır. 
Zeydîler, yine konu ile ilgili görüşlerini, çok yönlü delillerle temellendirmeye çalıştıktan sonra, kendi delillerine yapılan tenkitlere teker teker cevap vermişler ve muhaliflerinin delillerini titizlikle inceleyerek zayıf veya istidlal edilemeyecek özelliklere sahip olduklarını ortaya koymak için gayret göstermişlerdir.

Şu halde denilebilir ki Zeydîler, "lemese" ve "lâmese" kelimelerini, diğer bazı Sünnî kaynaklardan ve mezheplerden azamî derecede istifade ederek, ön yargıdan uzak ve daha tutarlı bir şekilde anlamaya çalışmışlardır. Bu sebeple Caferîlerin ile Zeydîlerin, söz konusu mesele hakkında lemese ve lâmesenin hiçbir şekilde abdesti bozmayacağını kabul etmelerine rağmen konuyu birbirlerinden çok farklı şekillerde değerlendirdikleri görülmüştür.

İbazilerin dokunma (lemese/lâmese) meselesine bakışlarına gelince; onların, Caferîler ve Zeydîlerden oldukça farklı noktadan konuyu ele aldıkları görülmektedir. Şöyle ki; onlar, karşı cinse mutlak anlamda dokunmanın abdesti bozduğunu söylemezler. Ne var ki, küçük veya büyük olduğuna bakılmadan, işlenen her türlü günahın abdesti bozduğunu savunurlar. Bu sebeple kişinin, eşi hariç, karşı cinsin veya hemcinsinin avret mahalline bakmasının ya da nâmahrem bir kadının bakılması caiz olan el ve yüz gibi azalarına şehvetle dokunmasının abdesti bozacağı görüşündedirler.

İbazîlerin, Caferîler ve Zeydîlerden farklı yönlerinden biri de şudur; onlar, ilk dönemlerde, abdesti bozan durumları ele alırken karşı cinse mutlak anlamda dokunmanın abdeste etkisinden pek bahsetmemişlerdir. O kadar ki, ilgili âyetleri mülâmese açısından değerlendirmedikleri gibi, ilk dönemlerde telif etmiş oldukları kitaplarda, mülâmesenin mutlak anlamda dokunma mı yoksa cimâ anlamında mı olduğuna da değinmemişlerdir. Fakat son dönemde (yaklaşık bir asır öncesinde) yazmış oldukları bazı eserlerinde, karşı cinse dokunmanın abdeste bir etkisinin olup olmadığını ilgili âyetler üzerinden, daha geniş bir bakış açısıyla ele aldıkları görülmüştür. Şöyle ki, konuyla ilgili görüşlerini temellendirirken Sünnî veya Şî̂ kaynaklarda yer aldığına bakmadan, her türlü rivâyeti, lugavî ve aklî delilleri kullanmışlardır. Ayrıca kendilerinden farklı görüşte olanların delillerini çürütmeye yönelik gayret gösterdikleri de görülmüştür. Ne var ki onlar, görüşlerine destek veren her türlü rivâyet ve delili tetkik etmeden veya sıhhat açısından teyit etmeden almışlardır.

Özetle İbâzilerin haram olan bakış ve dokunuşların abdesti bozacağı görüşü ayrı tutulacak olursa, Sünnî olmayan bu üç mezhep, karşı cinse dokunmanın abdesti bozmayacağı hususunda ittifak etmişlerdir. Ancak Caferîlerin, kendilerini masum imâmların görüşleri ve rivâyetleri ile sınırlandırarak mülâmese konusunda oldukça muhafazakâr davrandıklarını, Zeydîlerin nispeten mutedil olduklarını, İbâzîlerin ise, abdesti bozan hususları farklı telakki ettikleri için konuyu ayrıntılı olarak ele almadıklarını söylemek mümkündür.

\section{Kaynakça}

‘Âmilî, Muhammed b. Alî el-Mûsevî. Medâriku’l-ìhkâm Şerḥu Şerâii'il-ìlâm. tḥk. Müessesetü Âl-i Beyt li İhyâi't-Türâs. 9 Cilt. Meşhed/Îrân: Müessesetü Âl-i Beyt li İhyâi't-Türâs, 1410.

Beroje, Sahip. "Fıkıh Açısından Karşı Cinse Dokunmanın Abdeste Etkisi”. İslam Hukuku Araştırmaları Dergisi 30 (2017): 385-421.

Büceyremî, Süleymân b. Muhammed b. Ömer. el-Büceyremî ‘ale'l-Hatîib. 4 Cilt. Beyrut: Dâru'l-Kütübi'lİlmiyye, 1996. 


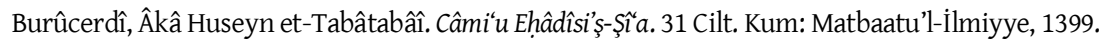

Cassâs, Ebû Bekr Ahmed b. Alî er-Râzî. Ahkkâmu'l-Kurân. Beyrut: Dâru İhyâi't-Türâsíi'l-'Arabî, 1412/1992.

Cevherî, Ebû Nasr İsmầîlb. Hammâd. eș-Șihâh Tâcü'l-Luġa ve Șihâhu'l-'Arabiyye. tḥk. Ahmed Abdulğafûr 'Attâr. 6 Cilt. Beyrut: Dâru'l-ìlm ve'l-Melâyîn, 2. Basım, 1399/1979.

Dâreḳuṭnî, Alî b. Ömer. Sünenü’d-Dâreḳutnî. tḥk.-tlk. Şu'ayb el-Arnavûṭ vd. Beyrut: Müessesetü’rRisâle, 2004.

Demir, Mahmut. "Sahabe-Ehl-i Beyt Ekseninde Şî̂-Sünnî İhtilafının Hadis Rivayetine Yansımaları”. e-Şarkiyat İlmî Araştrrmalar Dergisi 6 (2011), 90-111.

Ebû Dâvûd, Süleymân b. el-Eş'as es-Sicistânî. Sünenü Ebî Dâvûd. tḥk. Muhammed Muhyiddîn Abdulhâmid. Beyrut: el-Mektebetü'l-'Asriyye, ts.

Emîr es-San ‘̂nî, Muhammed b. İsmâ‘îl. Sübülü’’-Selâm ilâ Şerhi Bulûgi'l-Merâm. tḥk. -tlk. Muhammed Nâsıruddîn el-Elbânî. 4 Cilt. Riyâd: Mektebetü'l-Ma'ârif, 1427/2006.

Fîrûzâbâdî, Necduddîn, Muhammed b. Ya'kûb. el-Kâmûsu'l-Muhîț. Beyrut: Müessesetü’r-Risâle, 2005.

Garyânî, Sâvî Abdurrahmân. Müdevvenetü'l-Fikhi'l-Mâlikî ve Edilletuhu. 5 Cilt. Beyrût: Müessesetü'rReyyân, 1423/2002.

Gazâlî, Ebû Ḥâmid Muhammed b. Muhammed. el-iktitịâd fi'l-I'tikâd. Cidde: Dâru'l-Minhâc, 2. Baskı, $1433 / 2012$.

Gaznevî, Ebû Hafs Sirâcuddîn Ömer b. İshâk. Şerḥu ‘Akîdeti’ț-Ṭahaviyye. tḥk. Ḥâzim Geylânî el-HanefMuhammed Abdulkâdir Nassâr. Misır: Dâru'l-Kerez, 2009.

Göç, Emine Esin. “Lemsü’n-nisâ”nın Abdeste Etkisi Konusundaki Fıkhî Tartışmalar”. Marmara Üniversitesi İlahiyat Fakültesi Dergisi 35/2 (2008), 73-90.

Hasenî, Ahmed b. Huseyn el-Hârûnî. Şerhu't-Tecrîd fi Flḳhi'z-Zeydîyye. tḥk. Muhammed Yahyâ Sâlim Ezân - Hâmid Câbir 'Âbid. 6 Cilt. San'a/Yemen: Merkezü’t-Türâsi ve'l-Buhûsi'l-Yemenî, 1427/2006.

Haymî es-San'ânî, Şerefuddîn Huseyn b. Ahmed b. Huseyn. er-Ravżu’n-Nażîr Şerhu Mecmû'i'l-Flkhhi'lKebîr. 4 Cilt. Beyrut: Dâru'l-Cîl, ts.

İbn ‘Âşûr, Muhammed et-Tâhir. et-Tahrîr ve’t-Tenvîr. Tunis: Dâru’t-Tûnisiyye, 1984.

İbn Âbidîn, Seyyîd Muhammed Emîn b. Ömer b. Abdulazîz. Hâşsiyetu İbn Âbidîn (Reddü'l-Muhtâr 'ale'dDürril-Muhtâr). 12 Cilt. Beyrut: Dâru'l-Ma'rife, 2015.

İbn Hacer el-Heytemî, Şihâbuddîn Ahmed b. Muhammed b. Alî. Tuhfetu'l-Muhtâc fỉ Şerhi'l-Minhâc méa Hâsşiyeti’ş-Şirvânî ve Hâşsiyeti İbn Kâsim el-Abbâdî. tsḥ. Alî ‘Udde. 10 Cilt. Misir: el-Mektebetü’tTicâriyyeti'l-Kübrâ, 1357/1983.

İbn Hanbel, Ebû Abdillâh Ahmed b. Muhammed. Müsned. tḥk. Şu'ayb el-Arnavûṭ - Âdil Mürşid. 50 Cilt. Beyrut: Müessesetü'r-Risâle, 1995.

İbn Kesîr, Imâduddîn Ebu'l-Fedâ İsmâ̂îl. Tefsîru'l-Ḳur'âni'l-'Azîm. 15 Cilt. Kahire: Müessesetü'l-Kurtubâ/Mektebetü Evlâdi'ş-Şeyh li't-Türâsi, 1421/2000.

İbn Kudâme, Ebû Muhammed Muvaffakuddîn Abdullâh b. Ahmed. el-Muginî şerhu Muhtasari'l-Ḥ̌râkî. Dâru'l-Kütübi'l-ilmiyye, Riyâd.

İbn Mâce, Ebû Abdillâh Muhammed b. Yezîd el-Kazvinî. Sünen. tḥk. Muhammed Fuâd Abdulbâkî. b.y.: Dâru'l-Fikr, ts.

İbn Manzûr, Ebu'l-Fadl Cemâluddîn Muhammed b. Mukerrem el-Ifrikî el-Misrî. Lisânü'l-‘Arab. 15 Cilt. Beyrut: Dâru Sadr, 1414.

İbnu'l-Cezerî, Ebu'l-Hayr Muhammed b. Muhammed b. Alî b. Yûsuf. en-Neşru fi'l-Kıraâti'l-Aşsr. 2 Cilt. Beyrut: Dâru'l-Kütübi'l-ïlmiyye, ts.

İsfehânî, Ebu'l-Kâsım el-Huseyn b. Muhammed Râğib. el-Müfredât fí Garîbi'l-Ḳurân. tḥk. Muhammed Seyyîd Keylânî. Beyrut: Dâru'l-Ma'rife, ts.

Kahraman, Hüseyin. "Hadislere Göre Karş1 Cinse Dokunmanın Abdeste Etkisi”. Uludağ Üniversitesi İlahiyat Fakültesi Dergisi 19/1 (2010), 69-109. 
Kahraman, Hüseyin. "Hadislere Göre Kusmanın Abdeste Etkisi”. Uludağ Üniversitesi İlahiyat Fakültesi Dergisi 18/2 (2009), 152-182.

Kâsânî, Alâuddîn Ebû Bekr b. Mes'ûd. Bedâiu's-Sanâi fî́ Tertîbi'ş-Şerâi'. 7 Cilt. Beyrut: Dâru'l-Kütübi'l-İlmiyye, ts.

Kâşânî, Muhammed Muhsin el-F eyd. Tefsîru'ș-Ṣâfí. Meşhed: Dâru'l-Murtezâ, 2. Basım, 1402/1982.

Kindî, Muhammed İbrâhîm. Beyânu'ş-Şer. 38 Cilt. Mesḳaț/Ummân: Vezâretü’t-Türâsis'l-Kavmî ve'șSekâfe, 1405/1984.

Kummî, Ebû Ca'fer Muhammed b. Alîb. Huseyn b. Mûsâb. Bâbeveyh. Men lâ Yahżuruhu'l-Fakîh. Beyrut: Müessesetü'l-Âlemî, 1406/1986.

Kur'ân-ı Kerîm Meâli. çev. Halil Altuntaş - Muzaffer Şahin. Ankara: Diyanet İşleri Başkanlığı Yayınları, 14 Basım, 2012.

Bekir Kuzudişli, “Şầ'da Rivayet Olgusunu Şekillendiren Temel Unsurlar”, Dinbilimleri Akademik Araştorma Dergisi 18/1(2018), 59-95.

Küleynî, Muhammed b. Ya'kûb. el-Kâfi. Beyrut: Menşûrâtu'l-Fecr, 1428/2007.

Mağribî, Ebû Abdillâh Muhammed b. Muhammed. Mevâhibu'l-Hahîl. 8 Cilt. Beyrut: Dâru'l-Kütübi'l-illmiyye, ts.

Makbilî, Sâlih b. Mehdî. el-Menâr fi'l-Muhtâr min Cevâhiri'l-Bahri'z-Zahhâr. 2 Cilt. Beyrut: Müessesetü'rRisâle, 1408/1988.

Mâlik b. Enes, Ebû Abdillâh. el-Muvatța. tḥk. Beşşâr 'Avl Ma 'rûf. Beyrut: Dâru'l-Garbi'l-İslâmî, 2. Basım, 1417/1997.

Marifet, Muhammed Hâdî. et-Temhîd fí'Ulûmi'l-Kur'ân. Beyrut: Dâru't-Te'aruf li'l-Matbû'at, 1432/2011.

Mezfer, İsmânîl b. Mûsâ b. Ca'fer. Cafferiyyât. tḥk. Muştâk Sâlih. Kerbelâ: Isdâru Şu'beti't-Tahkîk, $1434 / 2013$.

Müslim, Ebu'l-Huseyn b. el-Haccâc. Șahîhu Müslim. tḥk. Muhammed Fuâd Abdulbâkî. Beyrut: Dâru İhyâi't-Türâsi'l'-'Arabî, ts.

Nesâî, Ebû Abdirrahmân Ahmed b. Şu'ayb b. Alî b. Sinân. Sünenü’n-Nesâ̂̀ (es-Suğrâ). tḥk. Abdulfettâh Ebû Ğudde. Haleb: Mektebetü'l-Matbû'ati'l-İslâmiyye, 1406/1986.

Nevevî, Ebû Zekeriyyâ Yahyâ. Ravżatu't-Ṭâlibîn. Beyrut: Dâru İbn Hazm, 1423/2002.

Nevevî, Ebû Zekeriyyâ Yahyâ. el-Mecmu Şerhu'l-Mühezzeb. tḥk..tlḳ. Muhammed Necîb Muțiî̀. Cidde: Mektebetü'l-İsşâd, ts.

Öz, Mustafa. "Ca 'fer es-Sadık”. Türkiye Diyanet Vakfi İslâm Ansiklopedisi. 7/1-3. Ankara: TDV Yayınları, 1993.

Öztürk, Mustafa. “İmâmiyye Şîası'nın Kıraat ve Ahruf-i Seba Anlayışı”. Marife 8/3 (Kış 2008): 121-154.

Remlî, Şemsuddîn Muhammed b. Ebi'l-Abbâs Ahmed b. Hamza b. Şihâbiddîn. Nihâyetu'l-Muhtâc ilâ Şerhi'l-Minhâc (eș-Şebrâmellisî ve el-Mağribî er-Reşîlînnin haşiyeleri ile birlikte). 8 Cilt. Beyrut: Dâru'l-Fikr, 1404/1984.

Sâlimî, Nûruddîn b. Abdullâh b. Hâmid. Me âricu'l-A'mâl 'alâ Medârici'l-Kemâl. 8 Cilt. Bidiye/Ummân: Mektebetü'l-İmâm es-Sâlimî, 2010.

Sübhânî, Cafer. Ușûlu'l-Hadîs ve Ahkâmuhu fî İlmi'd-Dirâye. Lübnan: Dâru Cevâdi'l-Eimme, 1444/2012.

Şemmâhî, ‘Âmir b. Alî. Kitâbu'l-îżâh. 4 Cilt. Meskaț/Ummân: Vezâretü't-Türâsis'l-Kavmî ve'ś-Sekâfe, 4. Basım, 1420/1999.

Şevkânî, Muhammed b. Alî b. Muhammed. Fethu'l-Kadîr el-Câmi'u beyne Fenneyi'r-Rivâyeh ve'd-Dirâyeh min Ilmitt-Tefsîr. tḥk. Abdurrahmân ‘Amîra. 5 Cilt. b.y.: Dâru'l-Vefâ, 1994.

Şevkânî, Muhammed b. Alî b. Muhammed. Neylül-Evțâr Şerhu Münteka'l-Ahbâr. tḥk. Ebû Mu'âz Târkk. 12 Cilt. Riyâd: Dâru İbni'l-Kayyim - Kahire: Dâru İbn Affân, 1426/2005.

Şeyh, Muhammed Sankur. “Messu'l-Mer'eti lâ Yankużu'l-Vużûe inde'l-İmâmiyye”. Huda'l-Kurûan. Erişim 17 Ekim 2019. http://hodaalquran.com/details.php?id=10040.

Şirbînî, Şemsuddîn Muhammed b. Ahmed el-Hुatîb. Mugini'l-Muhtâc ilâ Márifeti Elfâzi'l-Minhâc. 4 Cilt. İstanbul: Matbaatu Eser, 1377/1958. 
Tabersî, Ebû Alî el-Fadl b. Hasen. Mecma'u'l-Beyân fí Tefsîri'l-Ḳur'ân. Beyrut: Dâru'l-Murtezâ - Dâru'l'Ulûm, 1427/2006.

Tafeyyîş, Muhammed b. Yûsuf. Şerhu Kitâbi'n-Nîlve Şifâi'l-'Alîl. 17 Cilt. Cidde: Mektebetü'l-İrşâd-Beyrut: Mektebetü'l-Feth, ts.

Tenûhî (Sahnûn), Ebû Saîd Abdüsselâm b. Saîd b. Habîb. Müdevvenetü'l-Kübrâ. 6 Cilt. Beyrut: Dâru Sadr, ts (Eser kapakta İmâm Mâlik'e nispet edilmiştir).

Tirmizî, Ebû İsâ Muhammed b. İsâ b. Sevre İbn Mûsâ. Sünenü't-Tirmizî.tḥk. Ahmed Muhammed Şâkir. Kahire: y.y., 1357/1938.

Turay, Fatih. “Kanın Abdeste Etkisi”. Atatürk Üniversitesi İlahiyat Fakültesi Dergisi 43 (2015), 422-439.

Tûsî, Ebû Ca'fer Muhammed b. Alî b. Hasen b. Alî. el-ístibsâar. tḥk. Seyyîd Hasen el-Mûsevî Horesân. Tahran: Dâru'l-Kütübi'l-İslâmiyye, 4. Basım, 1363.

Tûsî, Ebû Ca'fer Muhammed b. Alî b. Hasen b. Alî. el-Mebsût fi Fiḳhi'l-Imâmiyye. Beyrut: Dâru'l-Kitâbi'lİslâmiyye, ts.

Tûsî, Ebû Ca‘fer Muhammed b. Alî b. Hasen b. Alî. Tehzîbu'l-Ahkâm fi Şerhị'-Mukni'a, tḥk. Alî Ekber elGafârî. 10 Cilt. Tahran: Dâru'l-Kütübi'l-İslâmiyye, 1385.

Tûsî, Ebû Ca'fer Muhammed b. Alî b. Hasen b. Alî. et-Tibyân fî Tefsîri'l-Kur'ân. Beyrut: Dâru İhyâi'tTürâsis'l-'Arabî, ts.

Yılmaz, Mustafa Kâzım. “Mecmau'l-Beyân”. Türkiye Diyanet Vakfi İslâm Ansiklopedisi. 28/257. Ankara: TDV Yayınları, 2003.

Zeyd b. Alî, Ebu'l-Huseyn. Müsnedü'l-Imâm Zeyd. Lübnan: Dâru'l-Kütübi'l-İlmiyye, ts. 